\title{
NONLINEAR INCENTIVE SCHEMES AND CORRUPTION IN PUBLIC PROCUREMENT: EVIDENCE FROM THE CZECH REPUBLIC
}

\section{Ján Palguta}

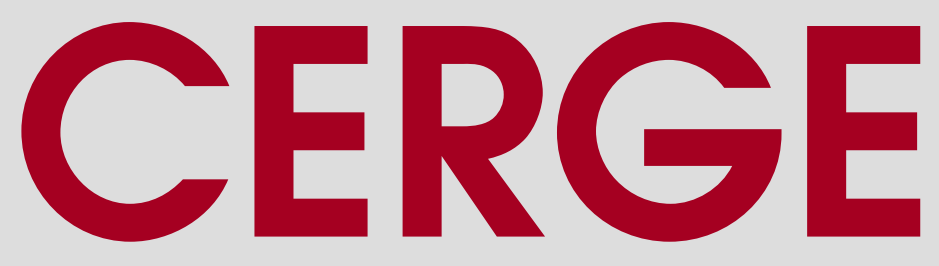




\section{Working Paper Series 483 (ISSN 1211-3298)}

\section{Nonlinear Incentive Schemes and Corruption in Public Procurement: Evidence from the Czech Republic}

Ján Palguta

CERGE-EI

Prague, March 2013 
ISBN 978-80-7343-287-4 (Univerzita Karlova. Centrum pro ekonomický výzkum a doktorské studium)

ISBN 978-80-7344-279-8 (Národohospodářský ústav AV ČR, v.v.i.) 


\title{
Nonlinear Incentive Schemes and Corruption in Public Procurement: Evidence from the Czech Republic
}

\author{
Ján Palguta*
}

\section{CERGE-EI ${ }^{\dagger}$}

\begin{abstract}
:
This article uses data on Czech public procurement contracts from 2005 - 2010 in order to uncover patterns suggestive of corrupt behavior of procuring officials. Using polynomial regressions and local linear density estimators, the article provides evidence that procurement officials manipulate anticipated values of procurements so that contracts can be awarded through less transparent procedures with restricted entry. Manipulations manifest through emergence of sharp discontinuities in the anticipated value distribution. Procurements excessively bunch below statutory thresholds, which determine officials' scope of discretion, entry-restrictiveness and transparency of the contract-awarding process. The first appearance of discontinuities coincides almost exactly with thresholds being introduced into the procurement legislation. Manipulations occur only in procedures restricted by thresholds and are prevalent only among a narrow group of procuring bodies. The last finding is consistent with manipulations being driven by corruption of procurement officials. Manipulations concern $8.6 \%$ of all below-limit procurements.
\end{abstract}

Keywords: public procurement, corruption, manipulation, incentives, statutory thresholds JEL classification: D73, H72, K42

\footnotetext{
* I would like to thank Libor Dušek, Randall Filer, Jan Hanousek, Peter Katuščák, Filip Pertold and Gerald Roland for their helpful comments and insightful suggestions. I would also like to thank Jakub Tomišek and Mário Vozár for excellent assistance in data collection. The support from the grant SVV-2012265801 and the GAUK grant No. 626712 is gratefully acknowledged. All errors remaining in this text are the responsibility of the author.

${ }^{+}$CERGE-El is a joint workplace of Charles University and the Economics Institute of the Academy of Sciences of the Czech Republic. Address: CERGE-EI, PO Box 882, Politických věznů 7, 11121 Prague, Czech Republic. Email: jan.palguta@cerge-ei.cz.
} 


\begin{abstract}
Abstrakt:
Článek používá data českých veřejných zakázek z let 2005-2010 a odkrývá vzorce korupčního jednání veřejných zadavatelů. Užitím polynomických regresí a lokálních lineárních estimátorů hustoty distribuce prokazuje, že zadavatelé manipulují s očekávanou hodnotou zakázek tak, aby zakázky mohly být zadávány méně transparentními postupy s omezenou účastí nabízejících. Manipulace zakázek se projevují vznikem ostrých nespojitostí v distribuci očekávané hodnoty zakázek. Zakázky se kumulují pod legislativnými limity, které skokovitě určují volnost jednání zadavatelů, omezenost vstupu dodavatelů do zadávácího soutěže a celkovou transparentnost zadávacího procesu. Článek prokazuje, že prvotní vznik nespojitostí časově přesně odpovídá zavedení limitů do legislativy veřejných zakázek. Nespojitosti vznikají pouze $\mathrm{v}$ procedurách omezených legislativními limity a jsou praktikovány pouze úzkou skupinou zadavatelů. Toto poslední zjištění je konzistentní s tvrzením, že k manipulacím dochází v důsledku korupčního jednání zadavatelů. Odhadujeme, že manipulace se týkají 8.6\% všech podlimitních zakázek.
\end{abstract}




\section{Introduction}

Corruption disturbs resource allocation all over the world. The costs are paid in terms of diversion of public resources away from public causes, which further translates into impediments to economic development and growth (Mauro 1995 and Bardhan 1997). Corruption may be detrimental to public sector of countries, because instead of offering contracts to the firms with best price-quality solutions, the contracts are given to firms offering greatest incentives to the officials.

While a large body of literature identifies culture as a key cause of corruption (Mauro 2004, Lambsdorff 2006, Fisman and Miguel 2007, Barr and Serra 2010), the growing field of forensic economics offers a complementary view and empirically documents that other factors - such as opportunities for corruption, level of accountability and the scope of officials' discretion - play an inseparable role in determining the prevalence of corruption (see Zitzewitz 2012 for a survey in forensic economics). In order to gain insights into how to effectively reduce corrupt behavior, opportunities and incentives that lead to corruption need to be clearly identified.

This paper contributes to the agenda of forensic economics by highlighting how a nonlinear structure of procurement regulation can create opportunities for corruption. The nonlinearity in procurement regulation emerges due to the presence of several statutory thresholds in the anticipated value of procurements. The thresholds discontinuously determine the scope of procuring authorities' discretion, the restrictiveness and the overall transparency of the contract-awarding process.

This paper demonstrates that the nonlinearity in the incentive scheme and induced corruption opportunities stimulate excessive manipulations of the anticipated value of procurements. Using a database of public procurement contracts from the Czech Republic from 2005-2010, I document the sudden emergence of several sharp discontinuities in the anticipated value of procurements. Using polynomial regressions and local linear estimators, I show that the first emergence of discontinuities followed shortly after the introduction of new anticipated value thresholds into the procurement legislation. Discontinuities appeared exactly at the points of procurement thresholds and only in procedures restricted by procurement thresholds. 
The Czech Republic proves to be an ideal laboratory for studying incentives for corruption. Firstly, it provides an excellent example of how, even in the absence of official datasets, an econometric analysis into corruption can be performed using micro data gathered by Web crawlers. Secondly, the public procurement in the Czech Republic is one of the spheres with the highest prevalence of corruption (Transparency International 2007, Pavel 2006). Thirdly and perhaps most importantly, the Czech Republic offers an excellent opportunity to exploit different sources of identification originating from the structure of and changes to procurement legislature.

The first approach to identification is based upon a nonparametric analysis of events that should be rare, assuming a given statistical model of the honest behavior of procuring officials. As a rare event, I consider an excess bunching of procurement contracts at specific points in the distribution of the anticipated value of procurements. Second, I use a major re-codification of Czech Public Procurement Act that occurred in July 2006, which allows me to demonstrate that the excess bunching of contracts emerged exactly at the points of new procurement thresholds and almost exactly after the new thresholds were established. Third, I use time variation in real prices of procurement contracts to show that excess contract masses clearly stick to the thresholds rather than following inflation over time.

Using polynomial regressions I estimate that the anticipated value manipulations concern $8.6 \%$ of all below-limit procurements awarded after the re-codification of the Public Procurement Act in July 2006. This accounts to $3.7 \%$ of all contracts after July 2006. These figures are quantitatively in line with previous estimates of corruption prevalence in procurement or in public service delivery (see survey by Svensson 2005).

The rest of the paper is organized as follows. Section 2 reviews related literature. Section 3 discusses the institutional framework of the Czech public procurement. Section 4 describes the data from procurement contracts. Section 5 presents the empirical analysis of manipulation of the anticipated values of contracts. Section 6 provides an alternative methodology for testing for manipulations of the anticipated value. Section 7 discusses the prevalence of manipulations across Czech public bodies. Section 8 summarizes the main findings and discusses policy implications. 


\section{Literature Review}

There has been much policy attention devoted to mechanisms, which incite illicit behavior in public domains, at least since the seminal contributions by Becker and Stigler (1974), Banfiled (1975) or Rose-Ackerman (1975). Corruption does not elude developed countries, although it is especially pronounced in countries with weak institutions (Shleifer and Vishny 1993). Numerous cross-country studies cite corruption as a serious impediment to economic development and growth (Mauro 1995 and Bardhan 1997).

In an effort to reduce corruption, many European countries have in recent years changed their public procurement regimes to open competitive procedures above specified financial thresholds. The European Commission advocates the use of more competitive and transparent procedures above thresholds by antidiscrimination and fostering European market integration (see Bulow and Klemperer 1996, Europe Economics 2006). For a comparison, the Federal Acquisition Regulations (FAR) in the United States also strongly favors the use of auctions in public procurement above legislative thresholds. FAR supports this preference by arguing for competitiveness, equal opportunity and corruption prevention (Tadelis 2009).

Generally, procurement thresholds are supposed to align the behavior of procuring officials with societal interests. At the same time, however, such high-powered nonlinear incentive schemes can yield rather perverse incentives (Holmstrom and Milgrom 1991 and Baker 1992). They are likely to induce behavioral distortions as agents seek to game the rules. The distortions may be particularly pronounced in systems with bright line rules (Gleaser and Shleifer 2001), as it is the case of this study.

Few studies have documented illicit or manipulative behavior generated by nonlinear incentives at thresholds. Wolfers (2006) analyzes corruption in NCAA basketball league, where the incentives for corruption derive from the nonlinear structure of the betting mechanism. McCrary (2008) analyzes the discontinuous pattern of roll call votes in the U.S. House of Representatives. Saez (2010) analyzes tax evasion using the bunching evidence of reported income, where bunching forms at various kinks of the 
US income tax schedule. Camacho and Conover (2011) document manipulation of a nonlinear targeting system for social welfare programs in Columbia. None of these papers, however, analyzes discontinuities in public procurement.

The only study related to thresholds in procurement is Coviello and Mariniello's (2012) paper, which exploits procurement thresholds in a regression discontinuity design. The authors study the impact of increased transparency in procurement above the procurement thresholds; however, they find no evidence of excess masses of contracts located at the thresholds. These authors do not focus on the nonlinear incentives for manipulating the procurement process.

My study is also unique as little previous empirical analysis of procurement corruption has been also documented from the side of procuring officials. The majority of empirical studies rather focus on collusion between bidders during the contractawarding process (Porter and Zona 1993, 1997, McMillan 1991, Baldwin, Marshall and Richard 1997 and many other). On the contrary, only two studies provided by DiTella and Schargrodsky (2003) and Bandiera, Prat and Valletti (2009) analyze corruption in procurement performed by procuring officials. The former study estimates the extent of procurement fraud in Argentinean public hospitals and finds a negative and welldefined effect of procuring officials`efficiency wages on prices paid for basic hospital inputs. In the latter study, the authors analyze the empirical relevance of passive versus active waste in Italian public procurement ${ }^{1}$. They find that some public procuring bodies pay systematically more than others for equivalent goods. The authors attribute the majority of waste to passive waste causes. Although both studies provide valuable insights into the motivations of the contracting officials, the incentives derived from the nonlinear structure of procurement regulation are largely neglected in these studies.

\footnotetext{
${ }^{1}$ Active waste entails direct or indirect benefit for the public official, typically due to corruption in form of a bribe. In contrast, passive waste results from the lack of skill or motivation of procurement officials to procure efficiently. The presence of passive waste does not benefit the officials.
} 


\section{Institutional Background}

Public procurement in the Czech Republic constitutes one of the largest public spending processes. Yearly, about $13-16 \%$ of GDP (USD 31 billion in 2010) is spent on procurement of goods, construction works and services - a figure which amounts to one of the largest procurement markets in OECD countries (Ministry of Regional Development 2012 and OECD 2010). Of this, approximately $50-55 \%$ falls under the regulation of the Czech Public Procurement Act and, therefore, under the scrutiny of this paper. The remaining $45-50 \%$ is allocated through small lots or legislative exemptions.

Four major legislative classifications determine the level of accountability and autonomy for procuring authorities in Czech public procurement. For this paper, the most important classification is by the anticipated value of procurements. The other classifications are by the main object of procurement, type of contract-awarding public body and type of contract-awarding procedure.

\subsection{Anticipated Value Procurement Thresholds}

The gist of classification by anticipated value rests in the fact that, although the Public Procurement Act sets out rules that all procuring bodies must comply, some rules apply only to procurements valued above relevant procurement thresholds.

The thresholds are legislatively set by the Public Procurement Act, but the procuring bodies estimate the anticipated value of procurements on their own. The rule is that the anticipated value must be estimated prior to the start of the contract-awarding process and the estimates should approximate the public bodies' anticipated obligations ensuing from the procurement. However, as it is shown later, public procuring bodies often set the procurements' anticipated values quite freely, so that milder legislative restrictions apply to the targeted procurement processes.

Several types of procurement thresholds are important for procuring authorities: thresholds for small lots, thresholds for above-limit contracts and thresholds specific to certain procurement procedures. 
The thresholds for small lots are of lesser importance in this study, because they only set out the lower bounds in procurement's anticipated value, above which the information about procurements is collected in the official evidence of procurements' records (see Table 1). Small lots are not regulated by the Public Procurement Act and only general rules regarding efficiency in procurement pertain to them.

More importantly, procurements other than small lots are split by procurement thresholds into below-limit procurements and above-limit procurements. The Public Procurement Act decrees the highest degree of transparency for above-limit procurements. Longer tendering deadlines apply to them and detailed information about them must be published in a European-wide database, Tenders Electronic Daily $(T E D)^{2}$. On the contrary, not all transparency standards are required in below-limit procurements. They have shorter tendering deadlines and information about them must be published only nationally-wide. National governments in the European Union can impose specific exemptions for below-limit procurements into their legislatures.

Some additional thresholds apply only to particular contract-awarding procedures. Procedures, which use anticipated value thresholds, are usually precluded from use if the anticipated value exceeds the relevant threshold. These procedures usually provide greater discretion to procuring officials below the threshold.

\subsection{Major Changes to Statutory Thresholds}

A large re-codification of the Czech public procurement code occurred in July $2006 .^{3}$ The re-codification caused movements in a majority of procurement thresholds (see Tables 2 and 3) and introduced a new type of simplified negotiating procedure into the procurement legislation.

\footnotetext{
${ }^{2}$ The information about TED contract notices is available from http://ted.europa.eu/TED/main/HomePage.do

${ }^{3}$ Until July 2006 public procurement had been regulated by Public Procurement Act no. 40/2004 Coll. Since then the public procurement is regulated by act no. 137/2006 Coll., as amended. The standing version of Public Procurement Act no. 137/2006 Coll. is available in English at:

http://www.portal-vz.cz/CMSPages/GetFile.aspx?guid=02f3f669-0f87-4f0e-913a-9bdfede93d36
} 
Simplified negotiations were a procurement procedure restricted by maximum thresholds of its own (Table 2). The reason for the introduction of a new procurement procedure was to offer the procuring officials the opportunity to free themselves from rigid rules, which regulated the open contract-awarding process above procurement thresholds. In a trade-off, the law demanded that the procuring authorities would invite at least five potential suppliers into each bidding process so as to guarantee some degree of competition.

A major controversy was that the decision of which competitors would be invited to bid was left at the full discretion of procuring authorities. In this way, the regulation created a strong opportunity and nonlinear incentive for authorities to engage in manipulations with anticipated values of procurement contracts.

The nonlinear incentive structure can promote manipulations with anticipated value through several means. The thresholds may tempt officials to solicit bribes in exchange for inflating the anticipated value of procurement, while holding it below the threshold, so that the contract can be via restricted entry and selective invitations of competitors more easily awarded to a contractor who offers a bribe. Alternatively, the officials can split large contracts into several smaller ones, each smaller contract procured slightly below the threshold. Thirdly, the procurement thresholds may provide incentives for officials to underestimate the value of contracts that would otherwise locate slightly above the thresholds. In this case, after the contract is procured, amendments are made as soon as the contractor who offers a bribe wins it.

Although the amount of surplus between a contractor offering a bribe and the authority who accepts it may vary across these manipulation techniques, all of them share the same theoretical prediction: excess masses of procurement contracts located just below procurement thresholds. 


\subsection{Other Classifications in Public Procurement}

Classification by the main object of procurements is easy, as the Public Procurement Act simply distinguishes between procurement of goods, construction works and services. Procurement thresholds differ by the main procurement object.

Next, the procurement code recognizes six contract-awarding procedures, which are described in greater detail in Appendix 1. The contract-awarding procedures differ in their degree of openness to potential suppliers and by the amount of external oversight applied to them. Public authorities can influence the choice of the contractawarding procedure through adjustments of the anticipated value of procurement. Some procedures then allow direct restrictions to the number of evaluated procurement bids, or they restrict the number of suppliers which are invited into procurement negotiations.

Lastly, procurement authorities are classified into national bodies, regional public bodies or state-owned utilities. Different thresholds apply to different types of public procuring bodies. The national bodies include national procurers and agencies, central government and its ministries. The regional bodies include regional and local bodies and their agencies. State-owned utilities are the national monopolies, such as energetic or gas companies or public transport providers. State-owned utilities are altogether forbidden to use the simplified negotiating procurement procedure. 


\section{Data from Public Procurement Contracts}

The available data on public procurement contracts includes characteristics of all procurements awarded in the Czech Republic during the period from 2005 to 2010, conditionally on their procurement process being governed at the relevant time by the Czech Public Procurement Act. The database therefore contains only information on contracts with anticipated value above the thresholds for small lots (see Table 1) and does not contain data on contracts procured through legislative exemptions. Altogether, this amounts to over 48,000 procurement contracts, while the total procurement volume in this investigation accounts to 1, 270 billion CZK (approximately 63.5 billion USD).

The data on procurement contracts were contract-by-contract screen-scraped from the Official website of Public Procurement (ISVZ). The Czech Ministry of Regional Development estimates that ISVZ contains information about approximately 50 - 55\% of the overall financial volume of public procurement performed in the Czech Republic. The size of this share has to do with high financial thresholds for small lots in the Czech Republic, which determine if information about a contract will be recorded in the official evidence of records.

The unit of observation in this study is a procurement project, although several contracts with different contractors may be procured within one project. The focus on projects rather than on contracts is because the anticipated value of procurements must be estimated at the level of an entire project, rather than separately for each contract.

For each project the database includes information on characteristics of the procured good/ service/ construction work, characteristics of the contract-awarding process, characteristics of procuring bodies, winning contractors and - most importantly - the anticipated values of procurements. From the dataset, this study disregards voluntarily disclosed information below thresholds for small lots, as well as voluntarily disclosed information about below-limit contracts procured by state-owned utilities. 
Table 4 provides the summary statistics of all residual contracts in two observation periods: before the major legislative re-codification of Public Procurement Act in July 2006 and afterwards. A general observation from Table 4 is that many procurement categories differ in their representation by an absolute count and procurement volume. For example, construction works are far more important when reweighted by procurement volume. They account for almost $60 \%$ of the total procurement value in the post- 2006 period, while they represent only $36 \%$ of data by the count of contracts. Also, the below-limit contracts are far more frequent in count than above-limit contracts; however, in volume they constitute just $22-29 \%$ of the total procured value.

Dataset composition by contract-awarding procedures evidently changed after the recodification of the Public Procurement Act in 2006. More than $20 \%$ of procurement volume moved from open procurement procedure to different kinds of negotiating procedures: to simplified negotiations, negotiations with prior public notice, or without it. ${ }^{4}$

Figure 1 then shows to what extent the procurement thresholds are important for determining which contract-awarding procedure will be used in procurement within the post-reform period. Figure 1 presents the relative shares of different contractawarding procedures in increasing anticipated value intervals. Simplified negotiations are predominantly represented only up to the construction works maximum threshold for simplified negotiations (20 million CZK). Above the threshold, only other types of procurement procedures may be used.

\footnotetext{
${ }^{4}$ Here, since the public procurements' evidence of records ISVZ does not clearly distinguish between simplified negotiations and negotiations with prior public notice, the two procedures are presented in a single category in this study. The Ministry of Regional Development of the Czech Republic, however, estimates that approximately $99 \%$ of contracts in this joint category (both by absolute count and procurement value) are procured through simplified negotiations (Ministry of Regional Development 2012).
} 


\section{Empirical Analysis of Anticipated Value Manipulations}

This section presents empirical evidence of manipulations of the anticipated value of procurement contracts by procurement officials. The subsections are organized by the three sources of empirical identification used in the paper. The fourth subsection provides an array of placebo tests which attempt to detect discontinuities in contractawarding procedures that are unrestricted by statutory procurement thresholds.

\subsection{Estimating the Counterfactual Distribution of Anticipated Value} I start with the identification technique, which is based upon an analysis of events that should be rare, assuming a given statistical model of honest behavior of procuring officials. The identification assumption, which underlies causal inferences about the effect of legislative thresholds on anticipated value manipulations, is that the anticipated value density distribution would be smooth if more restrictive tendering procedures were not prohibited above the legislative thresholds. ${ }^{5}$

Figure 2 plots the empirical distribution of the anticipated value of procurements for all construction contracts procured in the Czech Republic in 2006-2010. To construct this histogram, the difference between the actual anticipated value and the administrative threshold is calculated for each observation. Then the contracts are grouped into CZK 250,000 bins $(-14,000,000$ to $-13,750,000,-13,750,000$ to $-13,500,000$, etc.) on this re-centered anticipated value variable. Finally, Figure 2 plots the bin counts around the legislative threshold re-centered to zero.

Figure 2 shows that there is a spike below the simplified negotiations threshold in otherwise declining anticipated value distribution. To measure the excess mass of contracts below threshold $\mathrm{T}$, it is necessary to estimate a counterfactual density distribution - what the anticipated value distribution would look like if there was no ban on simplified negotiations above T. In order to estimate the counterfactual density, a polynomial is fitted to the counts plotted in the figure, excluding the data

\footnotetext{
${ }^{5}$ Studies of illicit behavior based on a statistical model of honest behavior were provided e.g. by Jakob and Levitt (2003) or Cramton and Schwartz (2000).
} 
below the threshold. This means that a polynomial regression of the following form is estimated:

$$
C_{j}=\sum_{i=0}^{q} \beta_{i}^{0} \cdot\left(Z_{j}\right)^{i}+\sum_{i=-R}^{0} \gamma_{i}^{0} \cdot \mathbf{1}\left[Z_{j}=i\right]+\varepsilon_{j}^{0}
$$

where $C_{j}$ is the number of contracts in anticipated value bin $j, Z_{j}$ is anticipated value relative to threshold in 250,000 CZK intervals $\left(Z_{j}=\{-55,-54, . ., 80\}\right)$, $q$ is the order of the polynomial, and $\mathrm{R}$ denotes the width of the excluded region below the threshold (measured in CZK 250,000).

Let $B_{N}$ denote the excess number of contracts that locate below the threshold. Moreover, let $b$ stand for the excess mass of contracts relative to the average density at the threshold. The initial estimate of the counterfactual distribution is defined as the predicted values from (1) omitting the contribution of the dummies below the threshold: $\hat{C}_{j}^{0}=\sum_{i=0}^{q} \hat{\beta}_{i}^{0} \cdot\left(Z_{j}\right)^{i}$. The excess number of contracts that locate below the threshold is $\hat{B}_{N}^{0}=\sum_{j=-R}^{0} C_{j}-\hat{C}_{j}^{0}=\sum_{i=-R}^{0} \hat{\gamma}_{i}^{0}$.

This calculation overestimates $B_{N}$ because it does not account for the fact that the additional contracts at the threshold come from points to the right of the threshold. That is, it does not satisfy the constraint that the area under the counterfactual must equal the area under the empirical distribution. To account for this problem, I shift the counterfactual distribution to the right of the threshold upward until it satisfies the integration constraint. Specifically, I define the counterfactual distribution $\hat{C}_{j}=$ $\sum_{i=0}^{q} \hat{\beta}_{i} \cdot\left(Z_{j}\right)^{i}$ as the fitted values from the regression:

$$
\text { (2) } \quad C_{j} \cdot\left(1+\mathbf{1}[j>0] \frac{\hat{B}_{N}}{\sum_{j=1}^{\infty} C_{j}}\right)=\sum_{i=0}^{q} \beta_{i} \cdot\left(Z_{j}\right)^{i}+\sum_{i=-R}^{0} \gamma_{i} \cdot \mathbf{1}\left[Z_{j}=i\right]+\varepsilon_{j}
$$

where $\hat{B}_{N}=\sum_{j=-R}^{0} C_{j}-\hat{C}_{j}=\sum_{i=-R}^{0} \hat{\gamma}_{i}$ is the excess number of contracts at the threshold implied by this counterfactual. ${ }^{6}$ Finally, I define my empirical estimate of $b$ as

\footnotetext{
${ }^{6}$ It is necessary to estimate (2) iteratively, because the dependent variable here depends upon the estimates of $\tilde{\beta}_{i}$. The excess mass $\hat{B}_{N}$ is iteratively recomputed using the estimated $\tilde{\beta}_{i}$ until a fixed point is reached. The bootstrapped standard errors that are reported below are adjusted for this iterative estimation procedure. A comparable counterfactual distribution correction is used for the example by Chetty et al. (2011).
} 
the excess mass below the threshold relative to the average density of the counterfactual anticipated contract value distribution between $-\mathrm{R}$ and 0 :

$$
\hat{b}=\frac{\hat{B}_{N}}{\sum_{j=-R}^{0} \hat{C}_{j} / R}
$$

The solid area beneath the empirical distribution in Figure 2 shows the counterfactual density $\left\{\hat{C}_{j}\right\}$ predicted using this procedure with a seventh-degree polynomial $(q=7)$ and a window of CZK 750,000 located just below the threshold $(R=3)$. With these parameters, I estimate $b=9.35$ - the excess mass below the threshold is $935 \%$ of the average height of the counterfactual distribution within CZK 750, 000 below the threshold. The first column of Table 5 presents these results. The qualitative results are not sensitive to changes in q or R or to the way in which the counterfactual is corrected to satisfy the integration constraint. ${ }^{7}$

I calculate a standard error for $\hat{b}$ using a parametric bootstrap procedure. I draw from the estimated vector of errors $\xi_{j}$ in (2) with replacement to generate a new set of counts and apply the technique above to calculate a new estimate $\hat{b}^{k}$. I define the standard error of $\hat{b}$ as the standard deviation of the distribution of $\hat{b}^{k}$ s. The standard error associated with my estimate of $b$ is 1.80 . The null hypothesis that there is no excess mass at the threshold relative to the counterfactual distribution is rejected with a t-statistics of 5.207.

Using the same methodology, the study also finds statistically significant evidence of manipulations with anticipated values of goods and services contracts. Figure 3 presents the visual inspection of these results, while the second and third columns of Table 5 summarize the results quantitatively. The estimated excess mass at threshold for goods contracts is $200 \%$ of the average height of the counterfactual distribution. The estimated excess mass at the threshold for services is $303 \%$ of the average counterfactual distribution height.

\footnotetext{
7 These qualitative results are also not sensitive to specifications accounting for other focal points located within the anticipated value distribution (for example located at substantial round figures within the distribution).
} 
By a quick back-of-the-envelope calculation the results from Tables 4 and 5 suggest that the anticipated value manipulations concern $8.6 \%$ of all below-limit procurement contracts awarded after the re-codification of the Public Procurement Act in July $2006 .^{8}$ This accounts to $3.7 \%$ of all contracts past July 2006 . These figures are quantitatively in line with the previous estimates of corruption prevalence in procurement or service delivery. For a comparison, see Svensson (2005).

\subsection{Exploiting the Timing of Introducing New Thresholds}

The identification assumption of the smooth counterfactual density distribution can be relaxed by exploiting the timing of introducing new thresholds into the procurement law. This approach allows me to overcome an important deficiency of the existing procurement studies, which were focused either only on specific procurement sectors or only on selected standardized products.

Figure 4 displays the distribution of procurements' anticipated value in each year from 2005-2010 for all construction works. In its subfigures, one can observe that the first appearance of contract bunching in 2007 coincides almost exactly with the introduction of the simplified negotiating threshold into the new procurement act (July 2006). In later years, the excess mass of contracts clings very closely to the legislative threshold. The yearly estimates of discontinuities are summarized in Table 6 . The recodification of the Procurement Act and the first emergence of discontinuities coincide perfectly in the cases of goods and services contracts. In the case of construction works, the discontinuity can be statistically detected only after a six month delay.

Explanations for the delay can vary. The new public procurement act constituted a substantial change in the public procurement system, so the procuring authorities might have needed several weeks or months to learn all administrative proceedings of the new legislature. The procuring authorities might have discovered the advantages of simplified negotiations only gradually through a learning and experience-sharing process.

\footnotetext{
${ }^{8}$ According to Tables 4 and 5, manipulations have occurred in 1,364 out of 15,865 below-limit procurements.
} 
On the contrary, one may argue here that the potential new opportunities for corruption were evident very soon and that simplified negotiations were less complex than other procedures, so there was not much to learn. Even in this case, the procuring authorities would have needed some time to discern the level of controlling authorities' oversight over the new procedure, especially over potential manipulations of the anticipated value of procurements.

Last, aside from the learning processes, the procurement process itself requires some amount of time until contracts are finalized and published in the Information system. Since the new law was passed in July 2006, the authorities may not have procured enough contracts in the last two quarters of 2006 so that anticipated value manipulations would become statistically significant sooner than 2007.

\subsection{Does Contract Bunching Follow Inflation or Does it Stick to Procurement Thresholds?}

It is still possible that at the time of the legislative re-codification a change in the governmental needs for construction projects that were worth approximately 20 million CZK occurred, and thus the needs coincided in size with the new procurement threshold for construction works. Such a change in governmental needs would have brought about a disproportionate representation of projects beneath the threshold even in the absence of any manipulation. However, one would then expect that the spike in the anticipated value density distribution, initially at 20 million, would shift with inflation over time.

Therefore, this section exploits the variation in real prices of construction works contracts over time. It uses the fact that procurement of construction works was restricted by a nominally stable threshold for several years since the re-codification in 2006 , while real prices in the construction industry were rising.

In Figure 5, I investigate whether the excess mass of construction contracts clings to the procurement threshold or tracks inflation over time. I consider the period from 2007 to 2010, during which the simplified negotiations threshold declined in real terms. Noting that the excess mass is located at the negotiations top threshold in 
2007, the figure shows two possibilities for its location in 2010: the 2010 threshold and the 2007 threshold adjusted for inflation in the construction industry.

Figure 5 shows that in the full sample of construction contracts, the excess mass clearly clings to the 2010 threshold rather than following inflation. If one may have conjectured that the mass of contracts below the threshold in 2007 was driven by specific needs for projects, the size of which coincided with the threshold in 2007, from Figure 5 one can infer that the procurement threshold is more important for contract bunching than specific governmental needs.

\subsection{Heterogeneity in Bunching across Procurement Procedures - Discontinuities at Placebo Thresholds}

There is a substantial heterogeneity in the amount of contract bunching at the thresholds for simplified negotiations across various types of procurement procedures. Figure 6 estimates the excess mass of contracts at the simplified negotiations threshold for three procedures, which are unrestricted by the simplified negotiations threshold. The investigated procedures include the open procurement procedure, the restricted procedure and the negotiating procedure without prior public notice. ${ }^{9}$

Figure 6 shows that in all three procedures a significant mass of contracts bunched below the procurement threshold cannot be statistically discerned. Table 7 summarizes the quantitative results. These "placebo tests" confirm that the primary source of excess mass below threshold is constituted by the overuse of the simplified negotiating procurement procedure.

\footnotetext{
${ }^{9}$ The procurement procedure of competitive dialogue was disregarded from Figure 5 due to a negligible number of contracts procured through competitive dialogue.
} 


\section{Robustness Checks}

In order to provide an alternative test of procurement contract bunching at the legislative thresholds, this section applies the McCrary`s (2008) density test on the available data of anticipated value of procurements. McCrary's (2008) test is commonly used for testing for undesirable sorting in the running variable in the regression discontinuity design. The test can be particularly useful in applications where a discontinuous density is itself the object of interest. Among such applications, Saez (2010) measures tax evasion using the density discontinuities in reported income.

McCrary`s test consists of a simple extension of the local linear density estimator from Cheng, Fan and Marron (1997). In a practical sense, it is implemented as a Wald test of the null hypothesis that the discontinuity at threshold $\mathrm{T}$ is zero. The estimator proceeds in two steps. In the first step, one obtains a finely-gridded histogram. In the second step one smoothes the histogram using a local linear regression, separately on either side of the selected threshold T.

The first-step histogram is based on the frequency table of a discretized version of the examined variable,

(4) $g\left(z_{j}\right)=\left\lfloor\frac{z_{j}-T}{w}\right\rfloor w+\frac{w}{2}+T \in\left\{\ldots, T-3 \frac{w}{2}, T-\frac{w}{2}, T+\frac{w}{2}, T+3 \frac{w}{2}, \ldots\right\}$

where $\lfloor a\rfloor$ is the greatest integer in a. ${ }^{10}$ The histogram bins are defined carefully, so that no bin includes points both to the left and to the right of the point of discontinuity T. An equi-spaced grid $X_{1}, X_{2}, \ldots, X_{L}$ of width $w$ covers the support of $g\left(z_{\mathrm{j}}\right)$. The (normalized) cell size for the $l^{\text {th }}$ bin is $Y_{l}=\frac{1}{n w} \sum_{j=1}^{n} \mathbf{1}\left(g\left(z_{j}\right)=X_{l}\right)$, while the first step histogram is the scatter-plot $\left(X_{l}, Y_{l}\right)$.

The second step smoothes the histogram using a local linear regression. The midpoints of the histogram bins are treated as a regressor, and the normalized counts of observations falling into the particular bins are treated as the outcome variable. Local linear smoothing is conducted separately for the bins to the right and left of the point of the discontinuity so as to account for potential discontinuity in the density.

\footnotetext{
${ }^{10}$ The greatest integer in $a$ is the unique integer $k$ so that $k \leq a<k+1$ ("round to the left").
} 
Formally, the density estimate is given by $\hat{f}(z)=\widehat{\Phi_{1}}$, where $\left(\widehat{\Phi_{1}}, \widehat{\Phi_{2}}\right)$ minimize $L\left(\Phi_{1}, \Phi_{2}, z\right)=\sum_{l=1}^{L}\left\{Y_{l}-\Phi_{1}-\Phi_{2}\left(X_{l}-z\right)\right\}^{2} K\left(\frac{X_{l}-z}{h}\right)\left\{\mathbf{1}\left(X_{l}>T\right) \mathbf{1}(z \geq T)+\right.$ $\left.\mathbf{1}\left(X_{l}<T\right) \mathbf{1}(z<T)\right\}, \mathrm{K}($.$) is a kernel function, here chosen as the triangle kernel$ $K(t)=\max \{0,1-|t|\}, h$ is the bandwidth, or the window width, which defines the observations that are included in the local regression. This way most weight is given to the bins nearest the point where one is trying to estimate the density. The entire density function, $f(z)$, is estimated by looping over the evaluation points $z$.

The estimate of density discontinuity and main parameter of interest is the log difference in height

$$
\theta=\ln \lim _{z \downarrow T} f(z)-\ln \lim _{z \uparrow T} f(z) \equiv \ln f^{+}-\ln f^{-}
$$

While one can estimate $f^{+}$and $f^{-}$using $\hat{f}(z)$ for $z$ just above and below $\mathrm{T}$, respectively, it is easier and more accurate to estimate two separate local linear regressions, one on either side of $\mathrm{T}$. The log difference of the coefficients on the intercepts then estimates $\theta$. Formally

$$
=\ln \left\{\sum_{X_{l}>T} K\left(\frac{X_{l}-T}{h}\right) \frac{S_{n, 2}^{+}-S_{n, 1}^{+}\left(X_{l}-T\right)}{S_{n, 2}^{+} S_{n, 0}^{+}-\left(S_{n, 2}^{+}\right)^{2}} Y_{l}\right\}-\ln \left\{\sum_{X_{l}<T} K\left(\frac{X_{l}-T}{h}\right) \frac{S_{n, 2}^{-}-S_{n, 1}^{-}\left(X_{l}-T\right)}{S_{n, 2}^{-} S_{n, 0}^{-}-\left(S_{n, 2}^{-}\right)^{2}} Y_{l}\right\}
$$

where $S_{n, k}^{+}=\sum_{X_{l}>k} K\left(\left(X_{l}-T\right) / h\right)\left(X_{l}-T\right)^{k}$

and $\quad S_{n, k}^{-}=\sum_{X_{l}<k} K\left(\left(X_{l}-T\right) / h\right)\left(X_{l}-T\right)^{k}$.

McCrary (2008) proves that under standard nonparametric regularity conditions, $\hat{\theta}$ is consistent and asymptomatically normal. An approximate implied standard error for $\hat{\theta}$ is

$$
\widehat{\sigma_{\theta}}=\sqrt{\frac{1}{n h} \frac{24}{5}\left(\frac{1}{\hat{f}^{+}}+\frac{1}{\hat{f}^{-}}\right)}
$$

The t-tests, constructed using this standard error, are shown to be very close to normally distributed under the null hypothesis.

Figure 7 presents the estimate of the density function of the anticipated value of public construction works' contracts. The curve was estimated using the local linear estimator outlined in this section with evaluation points $X_{1}, X_{2}, \ldots, X_{L}$. The bandwidth and bin size 
were selected subjectively after using an automatic procedure proposed by McCrary $(2008)^{11}$. The figure uses a bin size $w=250,000$ and a bandwidth $h=2,000,000$. The automatic procedure would select a bin size of $\mathrm{w}=191,313$ and a bandwidth $\mathrm{h}=$ $4,749,168$. The automatic procedure would over-smooth the histogram. ${ }^{12}$

Figure 7 strongly suggests that the underlying density function is discontinuous at the threshold for simplified negotiations (in the figure the threshold is re-centered to zero). Importantly, the first step histogram reveals that this is not the result of undersmoothing. Both the first step histogram and the local linear smoother indicate that contracts within hundreds of thousands of CZK of the threshold are much more likely to be procured below the threshold than above it.

Table 8 presents the parameters $\hat{\theta}$ estimated using local linear regressions for all types of the main object of procurements along with their respective simulated standard errors. ${ }^{13}$ The estimated log discontinuities are $-329.1 \%,-45.7 \%$, and $-80.1 \%$ for construction works, goods, and services contracts, respectively. All estimates are highly statistically significant with t-ratios of $-13.53,-4.4$ and -10.09 for construction works, goods, and services contracts, respectively. These results provide a robustness check consistent with the prior analysis of excess masses of contracts below the procurement thresholds for simplified negotiations.

\footnotetext{
${ }^{11}$ Pagan and Ullah (1999) and Deaton (1997) point out the effectiveness of subjective bandwidth choice.

12 McCrary (2008) states that for a fixed bandwidth, the estimator is robust to different choices of bin size, provided that $h / w>10$, which is the case in this specification.

13 I follow Horowitz (2001), Hall (1992) and McCrary (2008) and when estimating the standard error I under-smooth the local linear estimator by choosing a half bandwidth with respect to the reference bandwidth. The cited authors recommend this procedure in order to reduce the bias associated with a bandwidth which minimizes the asymptotic mean square error.
} 


\section{Discussion}

The advantage of an economic approach to identifying manipulative behavior is that it yields a clear understanding of the incentive structure that drives manipulations of anticipated value. Were there no thresholds in procurement legislature, there would be little contract bunching. Nonetheless, despite evidence of manipulations, one weakness of this study is that it is not capable of pinpointing whether manipulations are driven by active or passive waste. Active waste entails direct or indirect benefit for the public official, typically due to corruption. In contrast, passive waste can result from the lack of skill or motivation of procurement officials to apply more demanding procedures above thresholds.

This section discusses the available evidence regarding the potential of manipulations being driven by corruption. It evaluates to what extent the practice of contract bunching is concentrated among procuring authorities. This inspection can be useful for postulating policy recommendations, as different sources of waste require different policy changes.

\subsection{Concentration of Manipulations among Contracting Authorities}

The main conjecture about the concentration of manipulations among contracting authorities is as follows: if passive waste were driving the manipulations, excessive contract bunching should be typical across a large majority of authorities. For example, Bandiera, Prat and Valletti (2009) consistently find that passive waste accounts for a most of waste in a large majority of their sample procuring authorities. On the other hand, if manipulation is driven by active waste (and public bodies presumably differ in the degree of their corruptibility), significant differences in bunching across procuring authorities could be expected. For example, Olken (2006) finds that illicit behavior, in his case the theft of subsidized rice in Indonesia, was highly concentrated in only a small number of villages.

In order to assess the concentration of contract bunching at the level of procuring authorities, several measures of discontinuities in the anticipated value are created in this section (for a comparison see Camacho and Conover (2011)). All evaluated 
measures are calculated only for authorities that have carried out some minimal volume of procurement (100 million CZK) after 2006, when contract bunching was incentivized by procurement thresholds. This way, only large authorities with comparable volume of procurement are evaluated here.

The first and simplest measure of discontinuity is a difference in the procurement volume procured by each authority in a narrow radius ( $x$ million CZK) below and above the procurement threshold. If a procuring authority significantly bunches contracts below the threshold, the difference should be substantial. Secondly, I evaluate the same difference, but only for authorities that have generated positive discontinuities. In this way the discontinuity is assessed only at the intensive margin. Thirdly and fourthly, the same two discontinuity measures as before are presented; however, discontinuity is normalized by the total procurement volume procured by each authority. In order to ensure robustness, all measures are calculated for two bands with different widths around the threshold: for a band with a radius of 1.5 million CZK and a second band with a radius of 3.5 million CZK around the threshold. Table 9 summarizes the descriptive statistics of the discontinuity measures generated.

Table 9 demonstrates that, for large procuring authorities, there is, on average, 3.0 4.6\% more total procurement volume located below the threshold than above it. In absolute terms, this corresponds to $33.5-48.6$ million CZK per contracting authority. Nonetheless, some small positive difference is natural, as it follows from the declining statistical density distribution of the anticipated value of procurements.

The discontinuity conditional on positive observations is several times higher. On average $11.2-13.3 \%$ more of the total procurement volume is located below the threshold than above it. This corresponds to approximately $110-112$ million CZK per authority. The variance of all presented discontinuity measures is substantial.

Figure 8 presents the distribution of the normalized difference in the procurement volume awarded by authorities below and above the threshold (within the 3.5 million CZK radius from the threshold). Figure 8 shows that a substantial number of authorities produce relatively minor discontinuities, or none at all. The distribution of the discontinuity is positively skewed and has the following properties: for $66 \%$ of 
considered authorities, the difference in the volume of procurements below and above the threshold was not larger than $5 \%$ of the total volume of procurements. For $75 \%$ of authorities, the difference was lower than $10 \%$ of their total procurement volume.

On the other hand, in the upper decile of authorities with largest discontinuities, each authority has allocated at least $17 \%$ of total procurement volume more below the threshold than above it. The largest discontinuity reached $62.4 \%$ more total procurement volume below the threshold than above it.

Judging from numerous statistics, contract bunching is concentrated among a narrow group of procuring authorities. These authorities seem to artificially avoid open procurement procedures and to excessively restrict procurement competition through AV manipulations. Other procuring authorities apparently generate only minor discontinuities or none at all. 


\section{Conclusion}

This study has used publicly available data on public procurement contracts in order to uncover patterns suggestive of corrupt behavior. By nonparametric econometric methods, it has demonstrated that procuring officials in Czech public procurement apparently manipulate the anticipated values of procurement contracts in order for these contracts to be awarded through more restricted and less transparent procurement procedures. The incentive for officials to indulge in anticipated value manipulation and avoidance of open procurement was created by the nonlinear structure of procurement regulation. Below certain thresholds decreed by the Public Procurement Act, the procuring authorities have had, for example, sole discretion to invite any five contractors of their choice into the procurement process, excluding all others. Such nonlinearities have created opportunities and nonlinear incentives for corruption and generally active waste.

Considering all evidence is important when postulating policy recommendations. For example, should procurement officials be allowed to choose among procurement procedures more freely? This study has found that excessive contract bunching was typical only for a small fraction of authorities, while other procuring bodies were generating only minor discontinuities in the anticipated value. The underlying reason for excessively massing contracts, therefore, seemed to lie in the misalignment between the preferences of a minority of procurement bodies and those of society. The optimal delegation literature advises in such cases to call for stricter rules and external controls (e.g. Alonso and Matouschek 2008).

However, according to Kelman $(1990,2005)$ the policy of strict rules and external oversight can have detrimental effects if the underlying problem is indeed driven by passive waste and inefficiency. This seems to be the case of other authorities who generate minor discontinuities. Tadelis (2009) empirically demonstrates in his study that open procurement procedures, such as auctions, may perform poorly in cases when projects are complex, contractual design is incomplete or there are few available bidders. This may have been the case of many construction projects scrutinized in this 
study. Kelman $(1990,2005)$ advises in such cases to ease the rigidity of procurement, which would, in these circumstances, require altering procurement procedures above thresholds to be less administratively demanding and more flexible to the entry of additional competitors. The side effects may include increased procurement quality and reduced transaction costs.

The overall effect of increasing the effectiveness of procurement may be manifold: both through the direct effect on savings and optimization of contractor choice, and indirectly through increased competitiveness, transparency and trust in the fairness of the procurement process. The procurement environment would surely benefit from identification of its weak points.

Finally, a substantial advantage of this analysis is that it provides the controlling bodies with a new tool for analyzing fairness and manipulation in procurement competition. Under their limited resources, this analysis suggests that it may be worthwhile to investigate first those authorities which perform significant manipulations with the anticipated value of procurements. Forensic literature, moreover, teaches that even if anticipated value manipulations were themselves blameless, small-scale manipulations tend to be well-correlated with larger-scale malfeasance (Fisman and Miguel 2007, Zitzewitz 2012). Nonetheless, since the economic approach to identifying illicit behavior relies on recognizing systematic patterns emerging over large samples (Wolfers 2006), it is often beyond the reach of economists to pinpoint specific culprits. 


\section{References:}

ALONSO, R. and N. MATOUSCHEK (2008): “Optimal Delegation," Review of Economic Studies, 75(1), 259-293.

BAKER, G. (1992): "Incentive Contracts and Performance Measurement," Journal of Political Economy, 100(3), 598-614.

BALDWIN, L. and R. MARSHALL and J. RICHARD (1997): "Bidder Collusion at Forest Service Timber Sales," Journal of Political Economy, 105(4), 657-99.

BANDIERA, O. and A. PRAT and T. VALLETTI (2009): "Active and Passive Waste in Government Spending: Evidence from a Policy Experiment," American Economic Review, 99(4), 1278-1308.

BANFIELD, E. (1975): “Corruption as a Feature of Governmental Organization," Journal of Law and Economics, 18(3), 587-605.

BARDHAN, P. (1997): "Corruption and Development: A Review of Issues," Journal of Economic Literature, 35(3), 1320-46.

BARR, A. and D. SERRA (2010): "Corruption and Culture: An Experimental Analysis," Journal of Public Economics, 94(11-12), 862-69.

BECKER, G. and G. STIGLER (1974): "Law Enforcement, Malfeasance, and Compensation of Enforcers," The Journal of Legal Studies, 3(1), 1-18.

BULOW, J. and P. KLEMPERER (1996): “Auctions versus Negotiations," American Economic Review, 86(1), 180-94.

CAMACHO, A. and E. CONOVER (2011): "Manipulation of Social Program Eligibility," American Economic Journal: Economic Policy, 3(2), 41-65.

CHENG, M. and J. FAN and J. MARRON (1997): "On Automatic Boundary Corrections," The Annals of Statistics, 25(4), 1691-1708.

CHETTY, R. and J. FRIEDMAN and T. OLSEN and L. PISTAFERRI (2011): “Adjustment Costs, Firm Responses, and Micro vs. Macro Labor Supply Elasticities: Evidence from Danish Tax Records," The Quarterly Journal of Economics, 126(2), 749-804.

COVIELLO, D. and M. MARINIELLO (2012): "Publicity Requirements in Public Procurement: Evidence from a Regression Discontinuity Design," 
http://www.siecon.org/online/wp-content/uploads/2012/08/Coviello-Mariniello.pdf. CRAMTON, P. and J. SCHWARTZ (2000): "Collusive Bidding: Lessons from the FCC Spectrum Auctions," Journal of Regulatory Economics, 17 (3), 229-52.

DEATON, A. (1997): "The Analysis of Household Surveys: A Microeconomic Approach to Development Policy," Washington, D.C.: World Bank.

DI TELLA, R. and E. SCHARGRODSKY (2003): "The Role of Wages and Auditing during a Crackdown on Corruption in the City of Buenos Aires," Journal of Law and Economics, 46(1), 269-92.

EUROPE ECONOMICS (2006): "Evaluation of Public Procurement Directives," European Commission, DG Internal Market.

FISMAN, R. and E. MIGUEL (2007): “Corruption, Norms, and Legal Enforcement: Evidence from Diplomatic Parking Tickets," Journal of Political Economy, 115(6), 102048.

GLEASER, E. and A. SHLEIFER (2001): "A Reason for Quantity Regulation," American Economic Review, 91(2), 431-435.

HALL, P. (1992): "Effect of Bias Estimation on Coverage Accuracy of Bootstrap Confidence Intervals for a Probability Density," The Annals of Statistics, 20(2), 675694.

HOLSTROM, B. and P. MILGROM (1991): “Multitask Principal-Agent Analyses: Incentive Contracts, Asset Ownership, and Job Design," Journal of Law, Economics, and Organization, 7, 24-52.

HOROWITZ, J. (2001): "The Bootstrap," in The Handbook of Econometrics, eds. James J. Heckman and Edward Leamer, 5, pages 3463-3568. New York: Elsevier.

JACOB, B. and S. LEVITT (2003): "Rotten Apples: An Investigation of the Prevalence and Predictors of Teacher Cheating," The Quarterly Journal of Economics, 118(3), 843-877.

KAMENIK, M. (2011): “Otevřenost zadávacích řizení v ČR,” Prague: Oživení.

KELMAN, S. (1990): “Procurement and Public Management: The Fear of Discretion and the Quality of Public Performance," Washington, DC: The AEI Press. 
KELMAN, S. (2005): "Unleashing Change: A Study of Organizational Renewal in Government," Washington, DC: Brookings Institution Press.

LAMBSDORFF, J. G. (2006): "Causes and Consequences of Corruption: What Do We Know from a Cross-Section of Countries?" in International Handbook on the Economics of Corruption, ed. Susan Rose-Ackerman, pages 3-51. Cheltenham, UK: Edward Elgar.

MANELLI, A. and D. VINCENT (1995): “Optimal Procurement Mechanisms," Econometrica, 63(3), 591-620.

MAURO, P. (1995): “Corruption and Growth," Quarterly Journal of Economics, 110(3), 681-712.

MAURO, P. (2004): "The Persistence of Corruption and Slow Economic Growth," IMF Staff Papers, 51(1), 1-18.

MINISTRY OF THE REGIONAL DEVELOPMENT OF THE CZECH REPUBLIC (2012): "The Annual Report on the Condition of Public Procurement in the Czech Republic," Prague: Ministry of the Regional development of the Czech Republic.

MCCRARY, J. (2008): "Manipulation of the Running Variable in the Regression Discontinuity Design: A Density Test," Journal of Econometrics, 142(2), 698-714.

MCMILLAN, J. (1991): “Dango: Japan's Price-Fixing Conspiracies," Economics and Politics, 3(3), 201-218.

OECD (2010): “Government at a Glance 2009.” OECD Publishing.

OLKEN, B. (2006): "Corruption and the costs of redistribution: Micro evidence from Indonesia," Journal of Public Economics, 90(4-5), 853-870.

PAGAN, A. and A. ULLAH (1999): "Nonparametric Econometrics," New York: Cambridge University Press.

PAVEL, J. (2006): “Ukazatele transparentnosti trhu veřejných zakázek v České Republice," Prague: Transparency International - Czech Republic.

PORTER, R. and J. ZONA (1993): “Detection of Bid Rigging in Procurement Auctions," Journal of Political Economy, 101(3), 518-38.

PORTER, R. and J. ZONA (1999): “Ohio School Milk Markets: An Analysis of Bidding," RAND Journal of Economics, 30(2), 263-288. 
ROSE-ACKERMAN, S. (1975): "The economics of corruption," Journal of Public Economics, 4(2), 187-203.

SAEZ, E. (2010): “Do Taxpayers Bunch at Kink Points?" American Economic Journal: Economic Policy, 2(3), 180-212.

SHLEIFER, A. and R. VISHNY (1993): "Corruption," The Quarterly Journal of Economics, 108(3), 599-617.

SVENSSON, J. (2005): "Eight Questions about Corruption," Journal of Economic Perspectives, 19(3), 19-42.

TADELIS, S. (2009): "Auctions versus Negotiations in Procurement: An Empirical Analysis," Journal of Law, Economics and Organization, 25(2), 372-399.

TRANSPARENCY INTERNATIONAL CZECH REPUBLIC (2007): “Odhad neefektivně vynaložených veřejných zdrojů ve veřejných zakázkách," Prague: Transparency International - Czech Republic.

WOLFERS, J. (2006): "Point Shaving: Corruption in NCAA Basketball," American Economic Review, 96(2), 279-283.

ZITZEWITZ, E. (2012): “Forensic Economics,” Journal of Economic Literature, 50(3), 731-69. 


\section{Tables and Figures}

TABLE 1

Procurement Thresholds for Small Lots (in thousands CZK)

\begin{tabular}{lrrrrrr}
\hline \hline & $\mathbf{2 0 0 5}$ & $\mathbf{2 0 0 6}$ & $\mathbf{2 0 0 7}$ & $\mathbf{2 0 0 8}$ & $\mathbf{2 0 0 9}$ & $\mathbf{2 0 1 0}$ \\
\hline Goods and Services & 2,000 & 2,000 & 2,000 & 2,000 & 2,000 & 2,000 \\
Construction Works & 2,000 & $6,000^{*}$ & 6,000 & 6,000 & 6,000 & 6,000 \\
\hline \hline
\end{tabular}

Table 1 shows the annual procurement thresholds for small lots by a procurement's main object (in thousands of CZK). Small lots thresholds determine if the contract-awarding process is regulated by the Public Procurement Act. Procurements below the thresholds are not regulated by the Public Procurement Act and are also disregarded in official data-collection. Only general rules regarding efficiency and fair treatment of contractors pertain to small lots. ${ }^{*}$ The change in the small lots threshold is valid from July $1^{\text {st }}, 2006$.

TABLE 2

Procurement Thresholds for Simplified Negotiating Procedure (in thousands CZK)

\begin{tabular}{llrrrrrr}
\hline \hline & & $\mathbf{2 0 0 5}$ & $\mathbf{2 0 0 6}$ & $\mathbf{2 0 0 7}$ & $\mathbf{2 0 0 8}$ & $\mathbf{2 0 0 9}$ & $\mathbf{2 0 1 0}$ \\
\hline Goods and & - National Procurers & N/A & $4,290^{*}$ & 4,290 & 3,782 & 3,782 & 3,236 \\
& - Regional Bodies & N/A & $6,607^{*}$ & 6,607 & 5,857 & 5,857 & 4,997 \\
& - State-owned Utilities** & N/A & N/A & N/A & N/A & N/A & N/A \\
\hline $\begin{array}{l}\text { Construction } \\
\text { Works }\end{array}$ & & N/A & $20,000^{*}$ & 20,000 & 20,000 & 20,000 & 20,000 \\
\hline
\end{tabular}

Table 2 shows the annual procurement thresholds for simplified negotiations by the main object of procurements and the type of contract-awarding authority (in thousands of CZK). Simplified negotiations thresholds determine the scope of official discretion in inviting suppliers of their choice, entryrestrictiveness and overall transparency of the contract-awarding process. ${ }^{*}$ The introduction of simplified negotiations thresholds occurred on July $1^{\text {st }}$, 2006. **State-owned utilities are banned from using simplified negotiations. 
TABLE 3

Procurement Thresholds for Above-limit Contracts (in thousands CZK)

\begin{tabular}{llrrrrrr}
\hline \hline & & $\mathbf{2 0 0 5}$ & $\mathbf{2 0 0 6}$ & $\mathbf{2 0 0 7}$ & $\mathbf{2 0 0 8}$ & $\mathbf{2 0 0 9}$ & $\mathbf{2 0 1 0}$ \\
\hline Goods and & - National Procurers & 2,458 & $4,290^{*}$ & 4,290 & 3,782 & 3,782 & 3,236 \\
Services & - Regional Bodies & 6,550 & $6,607^{*}$ & 6,607 & 5,857 & 5,857 & 4,997 \\
& - State-owned Utilities & 13,100 & $13,215^{*}$ & 13,215 & 11,715 & 11,715 & 10,200 \\
\hline $\begin{array}{l}\text { Construction } \\
\text { Works }\end{array}$ & \multirow{2}{*}{163,750} & $165,288^{*}$ & 165,288 & 146,447 & 146,447 & 125,451 \\
\hline
\end{tabular}

Table 3 shows the annual procurement thresholds for above-limit contracts by the main object of procurements and type of contract-awarding authority (in thousands of CZK). The Public Procurement Act decrees the highest degree of transparency for above-limit procurements. Longer tendering deadlines apply and detailed information concerning their procurement has to be published in a European-wide database, Tenders Electronic Daily (TED). On the contrary, not all transparency standards are required to be met from authorities in below-limit procurements. ${ }^{*}$ The starred thresholds have been relevant since July $1^{\text {st }}, 2006$. 
TABLE 4

Descriptive statistics

\begin{tabular}{|c|c|c|c|c|c|c|c|c|}
\hline \multirow[b]{2}{*}{ Characterization: } & \multicolumn{4}{|c|}{ January 2005 - June 2006} & \multicolumn{4}{|c|}{ July 2006 - December 2010} \\
\hline & Contracts & (\%) & $\begin{array}{c}\text { Volume } \\
\text { (billion CZK) }\end{array}$ & (\%) & Contracts & (\%) & $\begin{array}{c}\text { Volume } \\
\text { (billion CZK) }\end{array}$ & (\%) \\
\hline \multicolumn{9}{|l|}{ By main object: } \\
\hline - Goods & 1,666 & 0.23 & 56.97 & 0.25 & 11,829 & 0.29 & 179.96 & 0.17 \\
\hline - Services & 1,221 & 0.17 & 48.25 & 0.21 & 14,603 & 0.35 & 247.87 & 0.24 \\
\hline - Construction works & 4,272 & 0.60 & 126.25 & 0.55 & 14,758 & 0.36 & 610.24 & 0.59 \\
\hline \multicolumn{9}{|l|}{ By contract-awarding procedure: } \\
\hline - Open & 5,534 & 0.77 & 197.03 & 0.85 & 20,331 & 0.49 & 662.41 & 0.64 \\
\hline - Restricted & 1,565 & 0.22 & 31.17 & 0.13 & 1,658 & 0.04 & 95.18 & 0.09 \\
\hline $\begin{array}{l}\text { - Simplified Negotiations and } \\
\text { Negotiations with Prior Public Notice* }\end{array}$ & 60 & 0.01 & 3.27 & 0.01 & 12,673 & 0.31 & 146.62 & 0.14 \\
\hline - Negotiations w/out Prior Public Notice & $\mathrm{N} / \mathrm{A}^{* *}$ & $\mathrm{~N} / \mathrm{A}^{* *}$ & $\mathrm{~N} / \mathrm{A}^{* *}$ & N/A** & 5,779 & 0.14 & 126.80 & 0.12 \\
\hline - Competitive Dialogue & $\mathrm{N} / \mathrm{A}^{* *}$ & $\mathrm{~N} / \mathrm{A}^{* *}$ & $\mathrm{~N} / \mathrm{A}^{* *}$ & $\mathrm{~N} / \mathrm{A}^{* *}$ & 25 & 0.00 & 2.32 & 0.00 \\
\hline \multicolumn{9}{|l|}{ By anticipated value: } \\
\hline - Below-limit contracts & 5,325 & 0.74 & 66.55 & 0.29 & 15,865 & 0.39 & 232.04 & 0.22 \\
\hline - Above-limit contracts & 1,834 & 0.26 & 164.93 & 0.71 & 21,292 & 0.52 & 806.40 & 0.78 \\
\hline \multicolumn{9}{|l|}{ By procuring authority's type: } \\
\hline - National Procurers & 3,418 & 51.60 & 119.85 & 0.52 & 22,985 & 0.56 & 561.19 & 0.54 \\
\hline - Regional Bodies & 3,462 & 48.36 & 58.16 & 0.25 & 16,587 & 0.40 & 306.33 & 0.29 \\
\hline - State-owned Utilities & 279 & 0.04 & 53.47 & 0.23 & 1,618 & 0.04 & 171.55 & 0.17 \\
\hline
\end{tabular}




\section{TABLE 5}

Polynomial Regressions Estimates of Excess Mass below Threshold

\begin{tabular}{cccc}
\hline \hline & $\begin{array}{c}\text { Construction } \\
\text { Works }\end{array}$ & Goods & Services \\
\hline \multirow{2}{*}{$\hat{b}$} & $9.352^{* * *}$ & $1.996^{* * *}$ & $3.027^{* * *}$ \\
& {$[1.850]$} & {$[0.236]$} & {$[0.275]$} \\
\hline$\hat{B}_{N}$ & 581 & 282 & 501 \\
$\mathrm{~N}$ & 8,830 & 5,228 & 6,357 \\
\hline
\end{tabular}

Table 5 shows the estimates of excess masses of contracts bunched below thresholds for simplified negotiations, estimated using the main specification outlined in section 5.1. Estimates are provided by the main object of the main procurements. A seventh-degree polynomial and a CZK 750,000 window located just below the threshold were used in order to predict the counterfactual density of the anticipated value of procurements. $\hat{B}_{N}$ denotes the estimated excess number of contracts below the threshold, and $\hat{b}$ denotes the excess mass of contracts relative to the average density at the threshold. Standard errors are presented in parentheses. ${ }^{* * *}$ Estimates significant at the $1 \%$ level. **Estimates significant at the $5 \%$ level. *Estimates significant at the $10 \%$ level.

\section{TABLE 6}

Estimated Excess Mass below Threshold by Year and Main Object

\begin{tabular}{|c|c|c|c|c|c|c|}
\hline \multirow[b]{3}{*}{ Year } & \multicolumn{2}{|c|}{ Construction Works } & \multicolumn{2}{|c|}{ Goods } & \multicolumn{2}{|c|}{ Services } \\
\hline & \multicolumn{2}{|c|}{ Excess Mass } & \multicolumn{2}{|l|}{ Excess Mass } & \multicolumn{2}{|c|}{ Excess Mass } \\
\hline & Estimates & SE & Estimates & SE & Estimates & SE \\
\hline 2005 & 2.861 & [1.902] & 0.410 & [0.552] & -0.025 & [0.577] \\
\hline 2006 & 2.628 & [1.891] & $1.635^{* * *}$ & [0.257] & $0.800 * * *$ & [0.294] \\
\hline 2007 & $12.100 * * *$ & [2.697] & $1.389 * * *$ & [0.427] & $3.162^{* * *}$ & [0.460] \\
\hline 2008 & $8.965 * * *$ & [1.651] & $1.799 * * *$ & [0.494] & $2.121^{* * *}$ & [0.478] \\
\hline 2009 & $11.190 * * *$ & [2.504] & $1.901 * * *$ & [0.522] & $2.503 * * *$ & [0.561] \\
\hline 2010 & $8.954 * * *$ & [1.990] & $2.362 * * *$ & [0.360] & $2.852 * * *$ & [0.371] \\
\hline
\end{tabular}

Table 6 shows the estimates of excess masses of contracts bunched below thresholds for simplified negotiations estimated using the main specification outlined in section 5.1. Estimates are provided by the main object of the procurements and observation period. A legislative re-codification, which established new thresholds into the procurement law, occurred in midyear 2006. A seventh-degree polynomial and a CZK 750,000 window located just below the threshold were used in order to predict the counterfactual density of the anticipated value of procurements. Estimates represent the estimated excess mass of contracts relative to the average density at thresholds. Standard errors are presented in parentheses. ${ }^{* * *}$ Estimates significant at the $1 \%$ level. ${ }^{* *}$ Estimates significant at the $5 \%$ level. *Estimates significant at the $10 \%$ level. 
TABLE 7

Estimated Excess Masses in Procedures Unrestricted by Procurement Thresholds

\begin{tabular}{cccc}
\hline \hline & Open & Restricted & $\begin{array}{c}\text { Negotiating } \\
\text { w/out Prior Public } \\
\text { Notice }\end{array}$ \\
\hline \multirow{b}{b}{} & 1.972 & 1.625 & 2.845 \\
$\mathrm{~N}$ & {$[1.494]$} & {$[1.683]$} & {$[1.606]$} \\
\hline \hline
\end{tabular}

Table 7 shows the estimates of excess masses of contracts for three procurement procedures, unrestricted by procurement thresholds. Excess masses are estimated at "placebo" thresholds, which locate at points in anticipated value distribution where simplified negotiations threshold would apply. The main specification outlined in section 5.1, equation 2 is employed in the estimation. Only construction works contracts from 2006 - 2010 are considered in the estimation. A seventh-degree polynomial and a CZK 750,000 window located just below the "placebo" thresholds were used in order to predict the counterfactual density of the anticipated value of procurements. Estimates represent the estimated excess masses of contracts relative to the average density at threshold. Standard errors are presented in parentheses. ${ }^{* * *}$ Estimates significant at the $1 \%$ level. ${ }^{* *}$ Estimates significant at the $5 \%$ level. *Estimates significant at the $10 \%$ level.

TABLE 8

Log Density Discontinuity Estimates

\begin{tabular}{cccc}
\hline \hline & Construction Works & Goods & Services \\
\hline \multirow{2}{*}{$\hat{\theta}$} & $-3.291^{* * *}$ & $-0.457^{* * *}$ & $-0.801^{* * *}$ \\
\multirow{2}{*}{$\mathrm{N}$} & {$[0.243]$} & {$[0.104]$} & {$[0.079]$} \\
\hline \hline
\end{tabular}

Table 8 presents the log estimates of discontinuity in the density of the anticipated value of procurements. Discontinuity estimates were obtained using a local linear density estimator described in section 6 . Simulated standard errors are presented in parentheses. ${ }^{* * *}$ Estimates significant at the $1 \%$ level. ${ }^{* *}$ Estimates significant at the $5 \%$ level. ${ }^{*}$ Estimates significant at the $10 \%$ level. 


\section{TABLE 9}

Density Discontinuities per Public Authority

\begin{tabular}{lrrrrr}
\hline \hline Radius around threshold: +/- 1.5 mil. CZK & Mean & SD & Min & Max & N \\
\hline AV Discontinuity: & & & & & \\
$\quad$ - in million CZK & 33.5 & 266 & -42 & 4,920 & 391 \\
- in million CZK cond. on positive discontinuity & 110 & 464 & 1.71 & 4,920 & 124 \\
\hline - relative to total volume by authority & .030 & .081 & -.175 & .506 & 391 \\
- relative to total volume by authority & .112 & .094 & .001 & .506 & 124 \\
$\quad$ cond. on positive discontinuity & & & & &
\end{tabular}

\begin{tabular}{lrrrrr}
\hline \hline Radius around threshold: +/- 3.5 mil. CZK & Mean & SD & Min & Max & N \\
\hline AV Discontinuity: & & & & & \\
$\quad$ - in million CZK & 48.6 & 396 & -60.3 & 7,470 & 385 \\
- in million CZK cond. on positive discontinuity & 112 & 577 & 1.29 & 7,470 & 178 \\
\hline - relative to total volume by authority & 0.046 & 0.119 & -0.366 & 0.624 & 385 \\
$\quad$ - relative to total volume by authority & 0.133 & 0.112 & 0.001 & 0.624 & 178 \\
$\quad$ cond. on positive discontinuity & & & & & \\
\hline \hline
\end{tabular}

Table 9 shows various measures of Anticipated Value (AV) Discontinuities calculated the level of individual public procuring authorities. Measures of discontinuity are calculated as a difference in procurement volume procured by an authority in a narrow radius above the threshold ( $x$ million CZK), minus the procurement volume in the same neighborhood below the threshold. The closer to 0 , the smaller the discontinuity at the threshold. Table 9 also shows AV discontinuities calculated only for authorities that generated positive discontinuities. Thirdly, Table 9 shows AV discontinuities in relative terms, which are the same discontinuities as before, only normalized by an overall procurement volume procured by a contracting authority. 


\section{FIGURE 1}

Procurements in Anticipated Value Intervals by Contract-Awarding Procedure

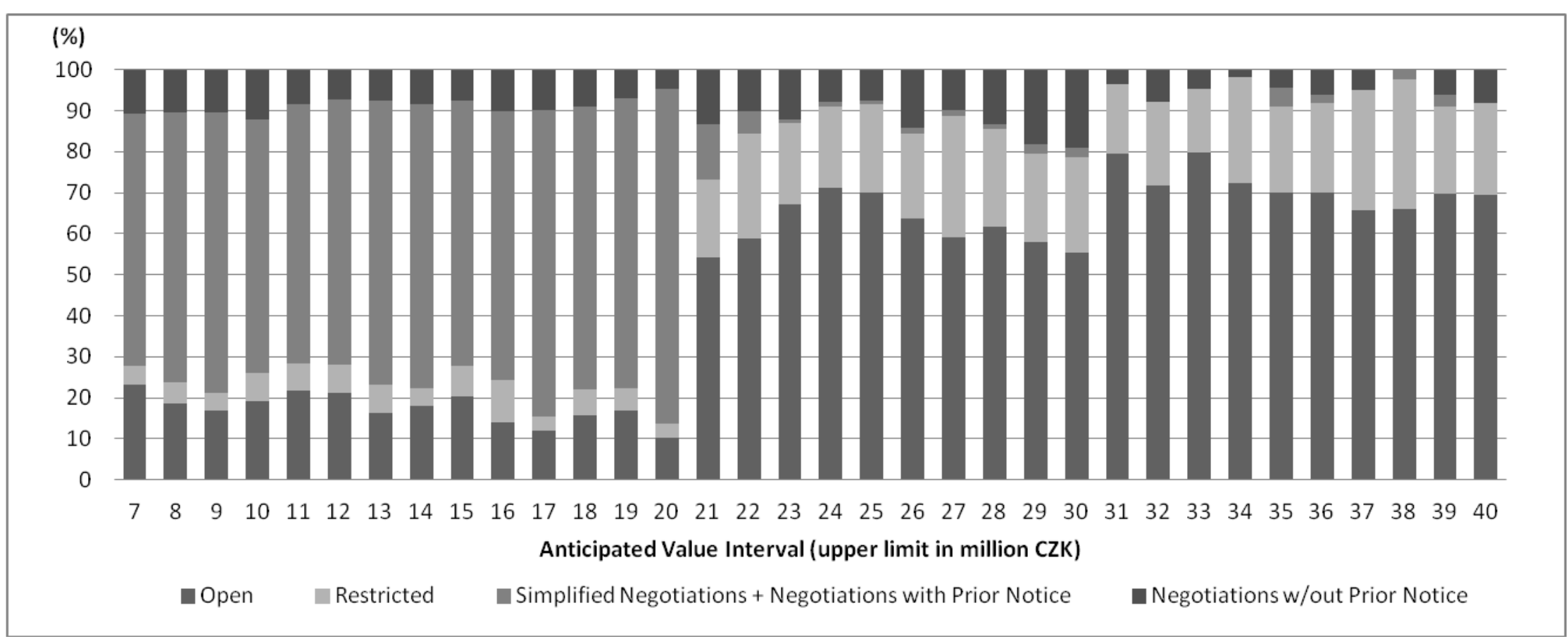

Figure 1 shows the structure of procurement contracts database by type of contract-awarding procedure in the 2006 - 2010 period (under the new Public Procurement Act). Contracts are divided into anticipated value intervals, each interval being 1 million CZK wide. Digits below bars denote the upper limit of anticipated value interval (in million CZK). Competitive dialogue is disregarded from the figure as it accounts for only a negligible number of contracts. Simplified negotiations and negotiations with prior public notice are presented jointly, due to the nature of the evidence of records of public procurement contracts. The figure is trimmed from below by a small lots threshold for construction works and from above by an arbitrary threshold of 40 million CZK. 20 million CZK is the statutory threshold for simplified negotiations of construction works. 
FIGURE 2

Anticipated Value Density Distribution around Threshold for Simplified Negotiations

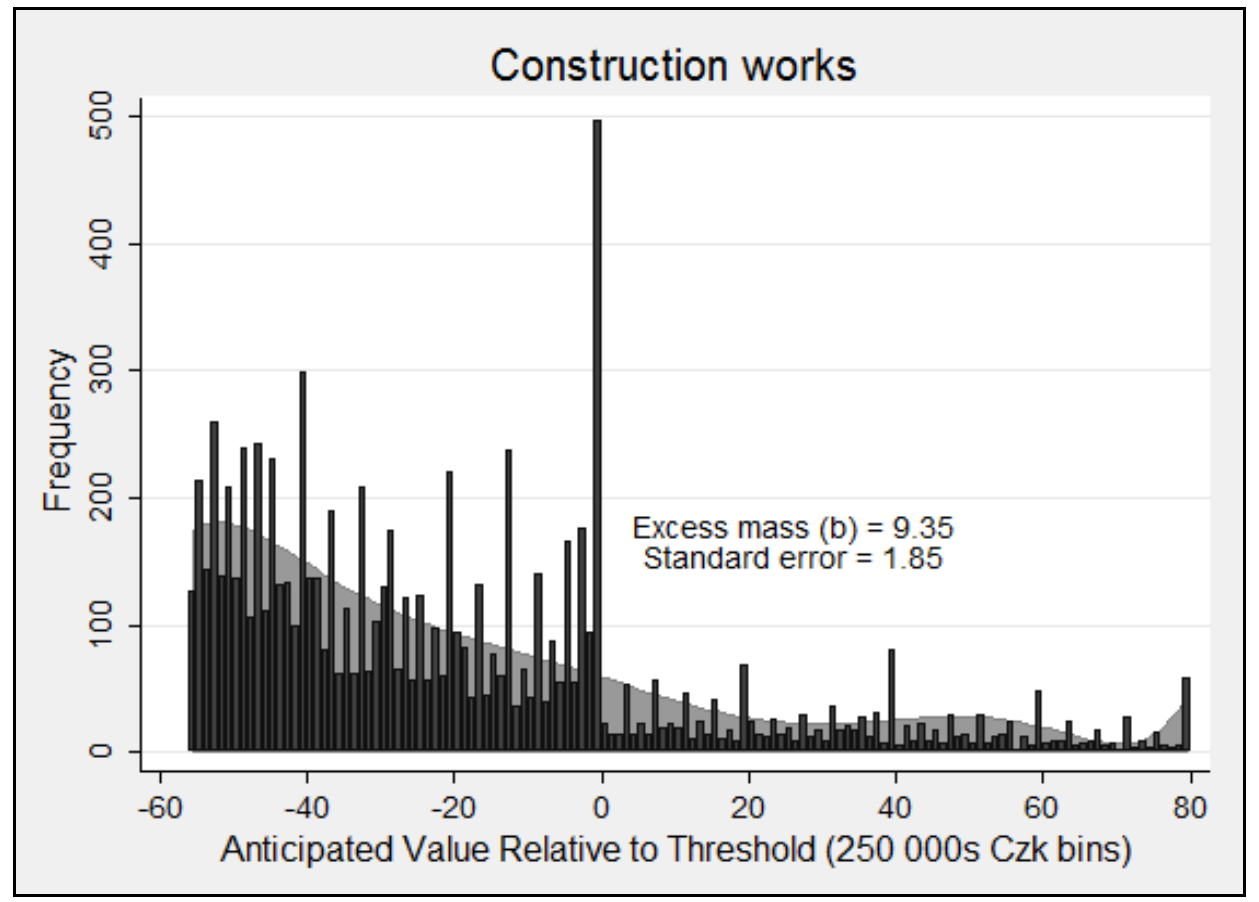

Figure 2 shows the distribution of the anticipated value of procurements around the threshold for simplified negotiations (re-centered to 0) for construction contracts between $2006-2010$. The series shown in bars is a histogram of the anticipated value of construction works, relative to the procurement threshold. Each bar shows the number of observations in CZK 250,000 bins. The solid distribution beneath the empirical distribution is a seventh-degree polynomial fitted to the empirical distribution, excluding the points CZK 750,000 or fewer below the threshold, as described in section 5.1, equation 2. The series is trimmed from below by a small lots threshold for construction works and from above by an arbitrary threshold of 40 million CZK. Otherwise, a full sample of construction contracts is considered. The estimated excess mass at the threshold is $935 \%$ of the average height of the counterfactual distribution beneath. 


\section{FIGURE 3}

Anticipated Value Density Distributions around Thresholds for Goods and Services
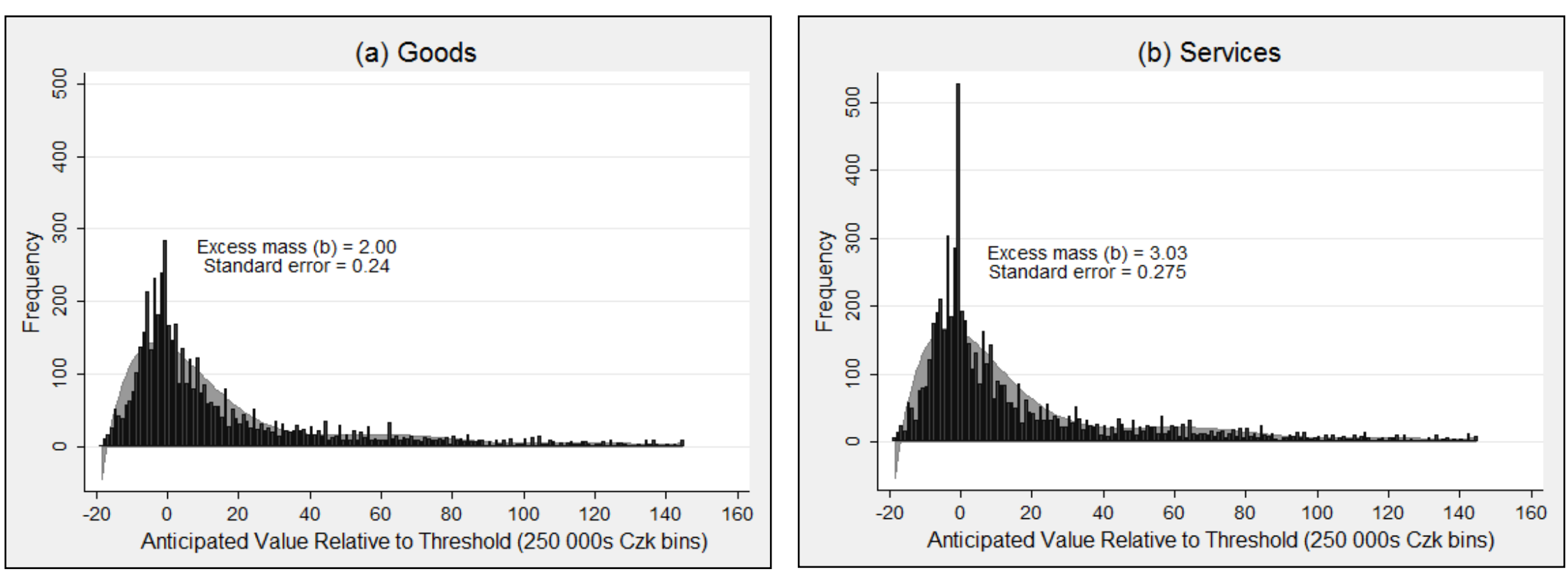

Figures 3 shows the distributions of the anticipated value of procurements around the thresholds for simplified negotiations (re-centered to 0). Panel (a) shows goods procurements and panel (b) services procurements. The series shown in bars are histograms of the anticipated value of procurements, relative to the procurement thresholds. Each bar shows the number of observations in CZK 250,000 bins. The solid distributions beneath empirical distributions are seventh-degree polynomials fitted to empirical distributions excluding the points CZK 750,000 or fewer below the threshold, as described in section 5.1, equation 2. The series are trimmed from below by small lots thresholds for goods and services and from above by an arbitrary threshold of 40 million CZK. Otherwise, full samples of goods and services contracts are considered. The estimated excess masses at the threshold are $200 \%$ and $303 \%$ of the average height of the counterfactual distributions beneath for goods and services contracts, respectively. 
FIGURE 4

Anticipated Value Distributions around Threshold for Simplified Negotiations by Years
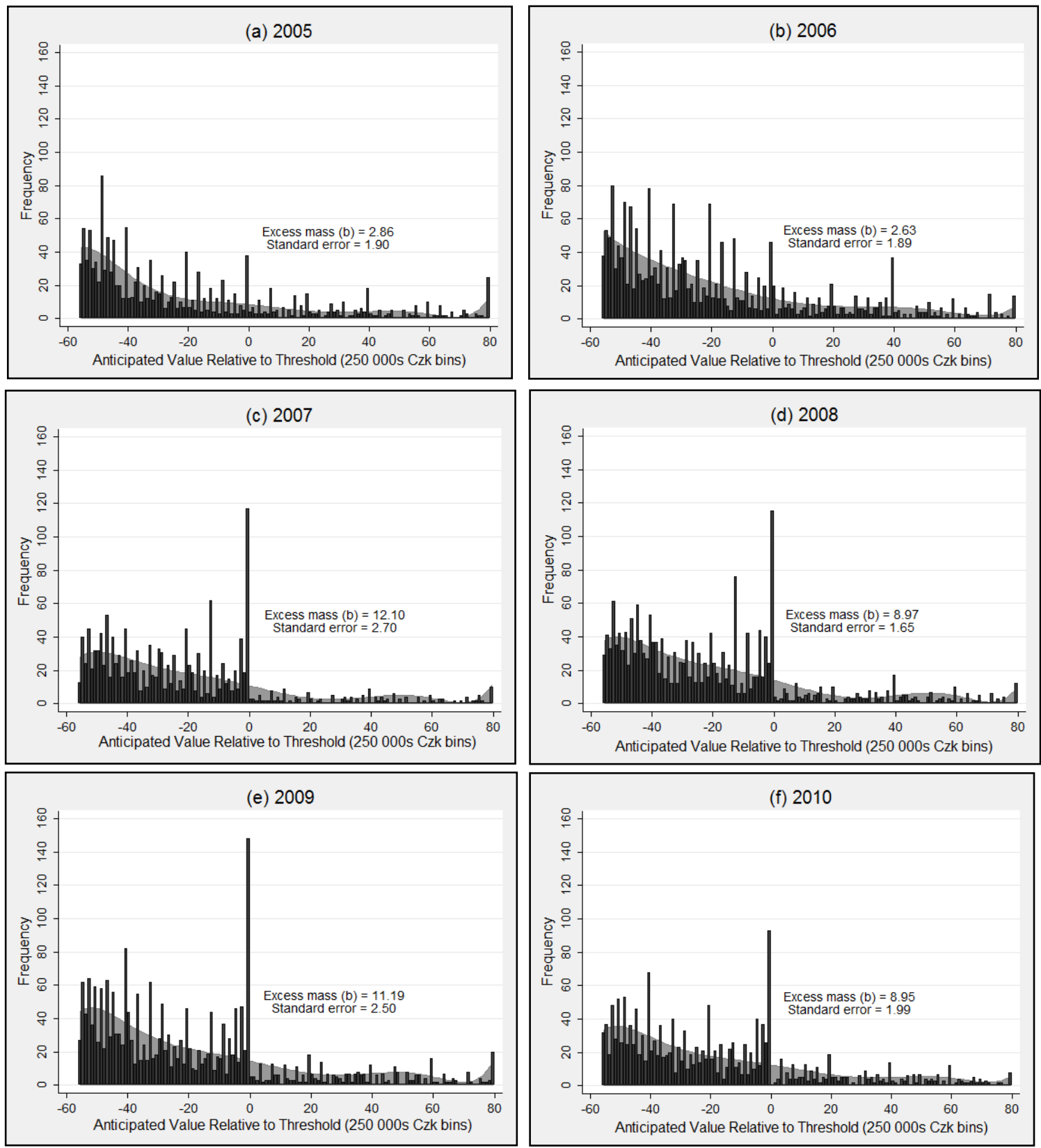

These figures show the distributions of the anticipated value of procurements around the thresholds for simplified negotiations for construction works in each year in 2005-2010. Thresholds are re-centered to 0 . Series shown in bars are histograms of the anticipated value of procurements relative to the thresholds. Each bar shows the number of observations in CZK 250,000 bins. The solid distributions beneath empirical distributions are seventh-degree polynomials fitted to empirical distributions, excluding the points CZK 750,000 or fewer below the threshold, as described in section 5.1, equation 2. The series are trimmed from below by small lots thresholds for construction works, and from above by an arbitrary threshold of 40 million CZK. Otherwise, the full sample of construction works contracts is considered. The estimated excess masses at the thresholds are presented in the first column of Table 5. 
FIGURE 5

Distinguishing Thresholds in Public Procurement from Inflation

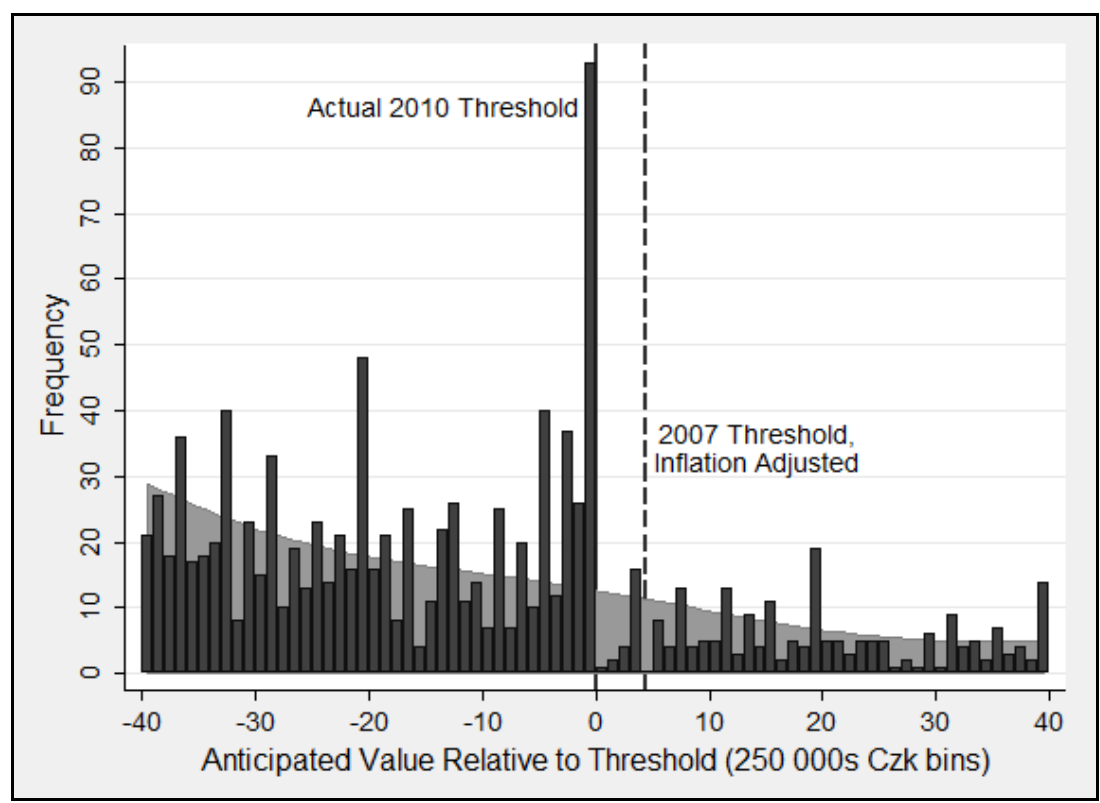

Figure 5 replicates the distribution of the anticipated value of procurements from Figure 4(f), zooming in around the simplified negotiations threshold. The location of the negotiations threshold in 2010 is marked with a solid line. The dashed line shows the level of the 2007 threshold adjusted for inflation in the Czech construction industry. 
FIGURE 6

Anticipated Value Distribution by Type of Procurement Procedure

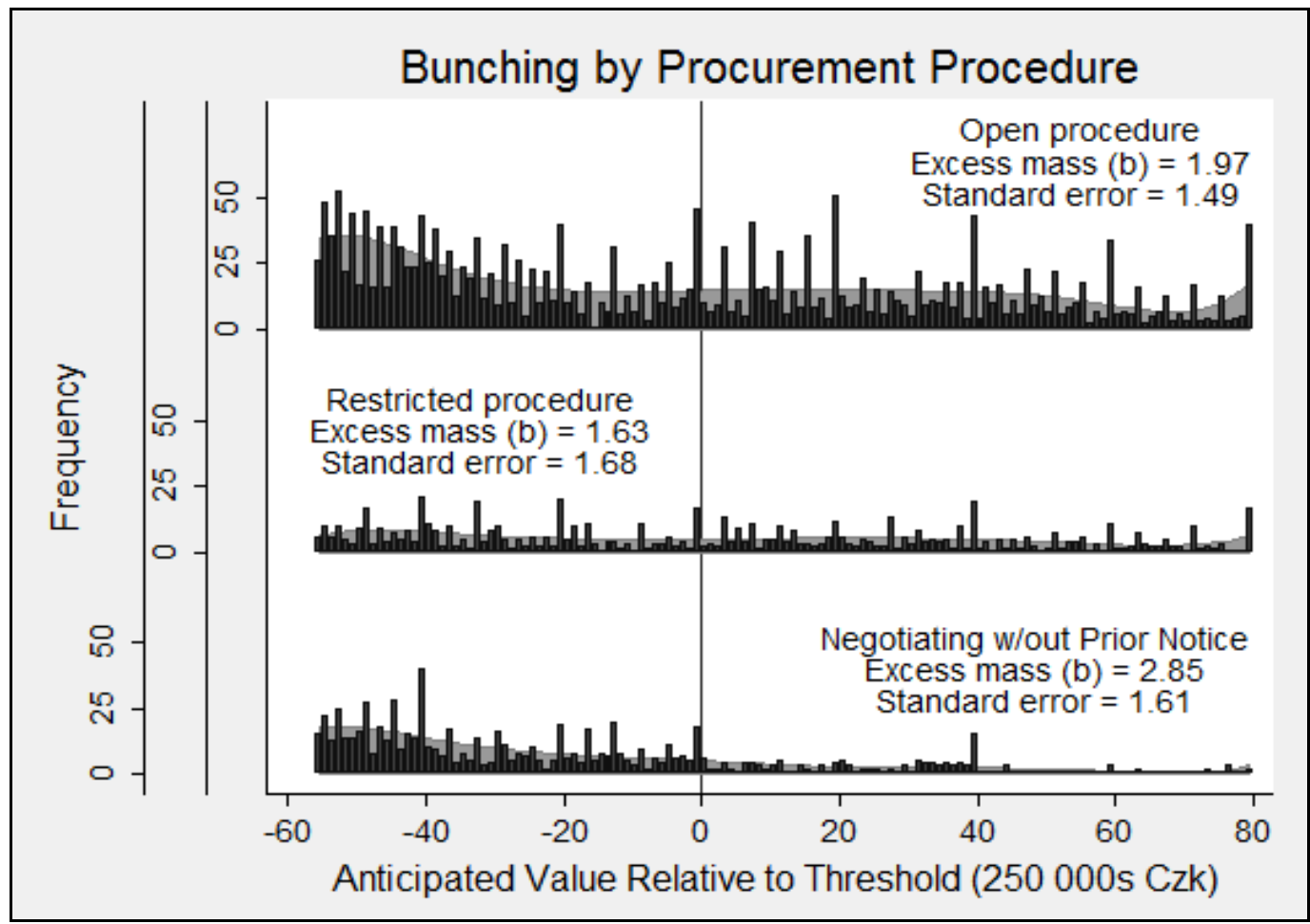

Figure 6 shows the distributions of the anticipated value of procurements around the "placebo" thresholds (demarcated by the vertical line at 0 ) in three contract-awarding procedures, which are unrestricted by procurement thresholds. Only construction contracts from $2006-2010$ are considered in the figure. "Placebo" thresholds locate at points, where simplified negotiation thresholds would locate. Series shown in bars are histograms of the anticipated value of procurements relative to the "placebo" threshold. Each bar shows the number of observations in CZK 250,000 bins. The solid distributions beneath empirical distributions are seventh-degree polynomials fitted to empirical distributions, excluding the points CZK 750,000 or fewer below the threshold, as described in section 5.1, equation 2. The top subfigure shows the series for contracts procured through an open procurement procedure. The middle subfigure depicts the series for contracts procured through a restricted procurement procedure. The bottom subfigure considers contracts procured through a negotiating procedure without prior public notice. The series are trimmed from below by small lots thresholds for construction works and from above by an arbitrary threshold of 40 million CZK. The estimated excess masses at "placebo" thresholds are presented in Table 6. 


\section{FIGURE 7}

Density of Anticipated Contract Value Estimated Using Local Linear Estimator

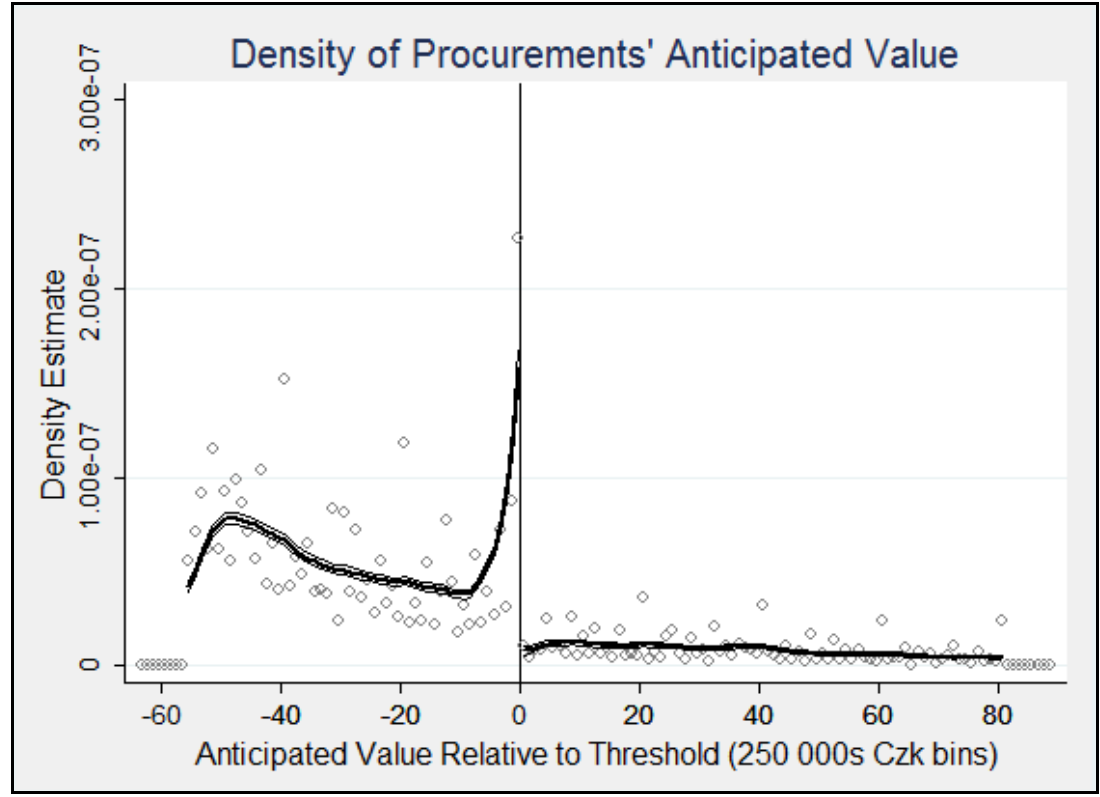

Figure 7 shows the density distribution of the anticipated value of procurements around the threshold for simplified negotiations (demarcated by a vertical line at 0 ). Only construction works contracts from $2006-2010$ are considered in the figure. The scatter-plot is a histogram of the anticipated value of procurements, relative to the simplified negotiations threshold. Each dot shows the density in CZK 250,000 bins. The solid line beneath the empirical distribution is a local linear smoother fitted to the empirical distribution estimated as described in section 6 . The figure shows the confidence interval of the estimator. For local linear smoother a bandwidth $\mathrm{h}=2,000,000$ is used. The figure is trimmed from below by the construction works small lots threshold and from above by an arbitrary threshold of CZK 40 million. The estimated log density discontinuity estimate for construction works at the simplified negotiations threshold is presented in the first column of Table 7. 


\section{FIGURE 8}

Size of the Anticipated Value Discontinuity per Procuring Authority

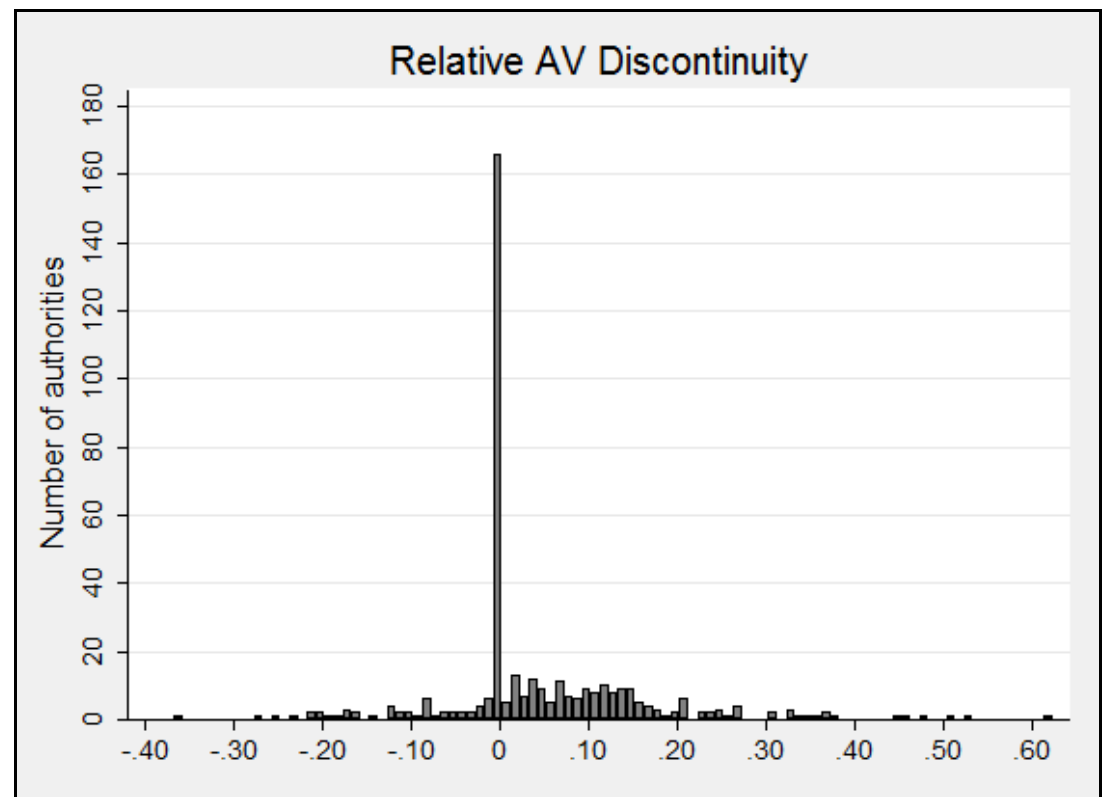

Figure 8 presents the heterogeneity in the size of anticipated value discontinuity at the construction works threshold for simplified negotiations for all public bodies that have procured at least 100 million CZK after the re-codification of Public Procurement Act in 2006. The discontinuity per procuring authority is measured as a difference in procurement volume awarded in a narrow band ( 3.5 million CZK) below the threshold, minus the procurement volume awarded in the same band above the threshold. The whole difference is normalized by the total procurement volume awarded by each public authority. The closer to 0 , the smaller the discontinuity at the threshold. The lower panel of Table 8 describes the summary statistics of the plotted heterogeneity in anticipated value density discontinuity. 


\section{Appendix 1 - Contract-Awarding Procedures}

Public authorities can control the level of openness of the tendering process through their choice of contract-awarding procedure. This appendix characterizes five procurement procedures recognized by the Public Procurement Act after its recodification in July 2006: an open procedure, a restricted procedure and 3 types of negotiating procedures: the negotiating procedure with prior public notice, without prior public notice and simplified negotiating procedure. ${ }^{14}$

Open procedure: In an open procedure a contracting authority announces its intention to procure a contract; it lays out its specifications and schedules a deadline for bidsubmission. An unrestricted number of firms may participate in the competition by submitting bids. Upon the deadline, the contracting authority reviews the fulfillment of prequalification criteria and, according to a set of pre-announced evaluation criteria, selects the most favorable bid. In the public procurement context this is the most transparent and open type of contracting procedure.

Restricted procedure: The procurement process consists of two phases in the restricted procedure. First, the contracting authority publishes its intention to procure a contract; it lays out the specifications and schedules a deadline for applications into the bidding phase. After the deadline, the second phase begins. The authority evaluates prequalification criteria and invites qualified firms to bid. The important distinction between the open and restricted procedures consists of the right of the authority not to invite all qualified firms to bid. The authority may restrict the number of bidders to any extent it desires so long as at least five applicants participate. The restriction should be based on a set of objective criteria, although if this is not feasible the authority may restrict the competition through a random ballot.

Negotiating procedures: The essence of the negotiating procedures is to allow the authority to discuss contractual terms with one or several potential suppliers.

\footnotetext{
${ }^{14}$ This appendix builds on a legal summary by Kamenik et al. (2011). The procurement procedure of competitive dialogue was disregarded from the legal summary due to a negligible number of contracts procured through competitive dialogue.
} 
Negotiations with prior public notice are in principle admissible only if the authority had previously unsuccessfully attempted to procure the contract via an open or restricted procedure. First, the public authority calls for applications for the bidsubmission phase. The applicants declare their interest by submitting their qualifications. Based on the delivered applications, the authority launches negotiations with the qualified bidders about the final version of their offers. The number of participants may be restricted to no less than three applicants, according to the same rules as in the restricted procedure.

Negotiations without prior public notice procedurally resemble the negotiations with prior notice, only in this case the negotiations take place prior to the bid-submission phase. A more important distinction lies in the legal conditions upon which the procedure may be used. These conditions either relate to previous unsuccessful attempts to procure the contract in a different type of procedure, or they describe the general conditions without the requirement for previous rounds of attempts. The conditions are vague and deliberately lessen the transparency of procurement. This procedure is typically used when technical or artistic considerations, the need for proprietorship protection, or other special legal circumstances are presumed to preclude contracting with other than one specific supplier. The procedure may also be used in cases of "emergency situations" that the procurement authority did not cause nor could have anticipated, and due to a shortage of time the contract cannot be procured through a different procedure.

The simplified negotiating procedure may be used only if the anticipated value of procurement does not exceed a relevant procurement threshold. The authority based on its own consideration selects any five potential suppliers and invites them into the bid submission phase. Although the procuring official is obliged to publish the procurement announcement on its own local online portal and to assess all submitted bids, including those of bidders who were not directly invited, there is only a limited chance that uninvited firms would participate in procurement. Which companies are included in the invitation is at the full discretion of the contracting authority. 


\section{Working Paper Series}

ISSN 1211-3298

Registration No. (Ministry of Culture): E 19443

Individual researchers, as well as the on-line and printed versions of the CERGE-EI Working Papers (including their dissemination) were supported from institutional support RVO 67985998 from Economics Institute of the ASCR, v. v. i.

Specific research support and/or other grants the researchers/publications benefited from are acknowledged at the beginning of the Paper.

(c) Ján Palguta, 2013

All rights reserved. No part of this publication may be reproduced, stored in a retrieval system or transmitted in any form or by any means, electronic, mechanical or photocopying, recording, or otherwise without the prior permission of the publisher.

Published by

Charles University in Prague, Center for Economic Research and Graduate Education (CERGE) and

Economics Institute ASCR, v. v. i. (EI)

CERGE-EI, Politických vězňů 7, 11121 Prague 1, tel.: +420 224005 153, Czech Republic.

Printed by CERGE-EI, Prague

Subscription: CERGE-EI homepage: http://www.cerge-ei.cz

Phone: + 420224005153

Email: office@cerge-ei.cz

Web: http://www.cerge-ei.cz

Editor: Michal Kejak

The paper is available online at http://www.cerge-ei.cz/publications/working_papers/.

ISBN 978-80-7343-287-4 (Univerzita Karlova. Centrum pro ekonomický výzkum a doktorské studium)

ISBN 978-80-7344-279-8 (Národohospodářský ústav AV ČR, v. v. i.) 
CERGE-EI

P.O.BOX 882

Politických vězňů 7

11121 Praha 1

Czech Republic http://www.cerge-ei.cz 